NATIONAL LABORATORY

MANAGED BY UT-BATTELLE

FOR THE DEPARTMENT OF ENERGY

\title{
Evaluation of 2004 Toyota Prius Hybrid Electric Drive System Interim Report
}

\author{
C. W. Ayers \\ J. S. Hsu \\ L. D. Marlino \\ C. W. Miller \\ G. W. Ott, Jr. \\ C. B. Oland
}

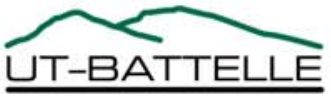




\title{
DOCUMENT AVAILABILITY
}

Reports produced after January 1, 1996, are generally available free via the U.S. Department of Energy (DOE) Information Bridge.

Web site http://www.osti.gov/bridge

Reports produced before January 1, 1996, may be purchased by members of the public from the following source.

\author{
National Technical Information Service \\ 5285 Port Royal Road \\ Springfield, VA 22161 \\ Telephone 703-605-6000 (1-800-553-6847) \\ TDD 703-487-4639 \\ Fax 703-605-6900 \\ E-mail info@ ntis.fedworld.gov \\ Web site http://www.ntis.gov/support/ordernowabout.htm
}

Reports are available to DOE employees, DOE contractors, Energy Technology Data Exchange (ETDE) representatives, and International Nuclear Information System (INIS) representatives from the following source.

Office of Scientific and Technical Information

P.O. Box 62

Oak Ridge, TN 37831

Telephone 865-576-8401

Fax 865-576-5728

E-mail reports@adonis.osti.gov

Web site http://www.osti.gov/contact.html

This report was prepared as an account of work sponsored by an agency of the United States Government. Neither the United States Government nor any agency thereof, nor any of their employees, makes any warranty, express or implied, or assumes any legal liability or responsibility for the accuracy, completeness, or usefulness of any information, apparatus, product, or process disclosed, or represents that its use would not infringe privately owned rights. Reference herein to any specific commercial product, process, or service by trade name, trademark, manufacturer, or otherwise, does not necessarily constitute or imply its endorsement, recommendation, or favoring by the United States Government or any agency thereof. The views and opinions of authors expressed herein do not necessarily state or reflect those of the United States Government or any agency thereof. 
ORNL/TM-2004/247

ENGINEERING SCIENCE \& TECHNOLOGY DIVISION

\title{
EVALUATION OF 2004 TOYOTA PRIUS HYBRID ELECTRIC DRIVE SYSTEM INTERIM REPORT
}

\author{
C. W. Ayers \\ J. S. Hsu \\ L. D. Marlino \\ C. W. Miller \\ G. W. Ott, Jr. \\ C. B. Oland \\ November 2004 \\ Prepared for the \\ U.S. Department of Energy \\ FreedomCar and Vehicle Technologies Program \\ Prepared by the \\ OAK RIDGE NATIONAL LABORATORY \\ Oak Ridge, Tennessee 37831 \\ managed by \\ UT-BATTELLE, LLC \\ for the \\ U.S. DEPARTMENT OF ENERGY \\ under contract DE-AC05-00OR22725
}




\section{TABLE OF CONTENTS}

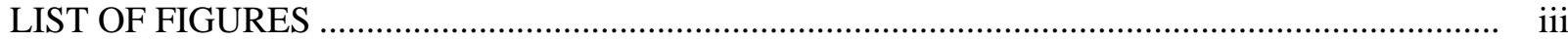

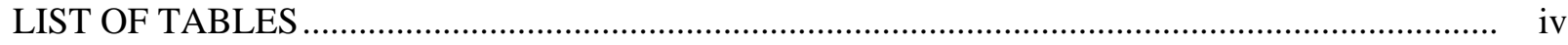

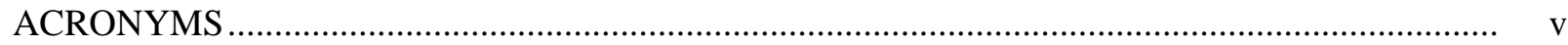

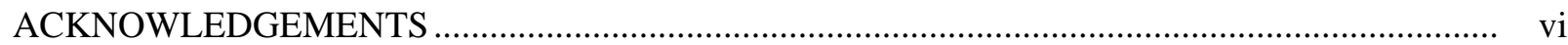

ABSTRACT

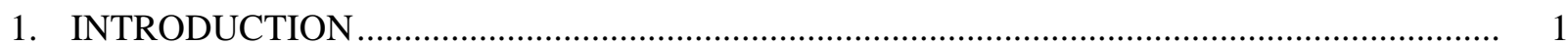

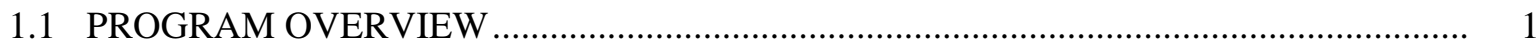

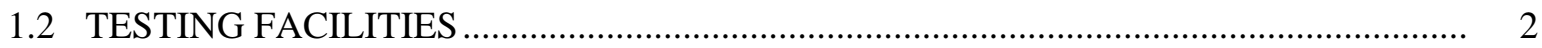

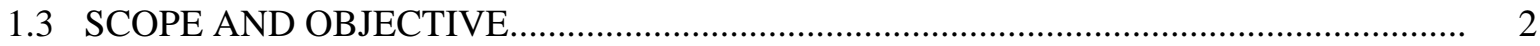

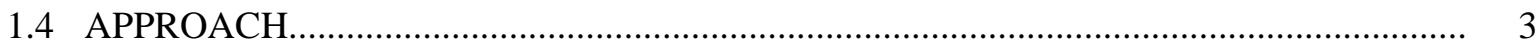

2. HYBRID ELECTRIC DRIVE SYSTEM DESCRIPTION …............................................... 4

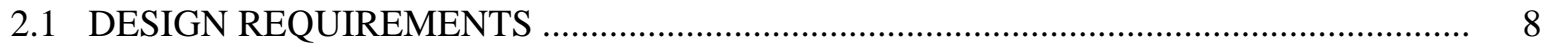

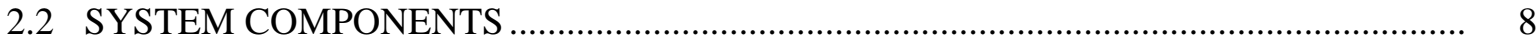

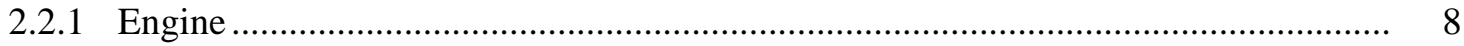

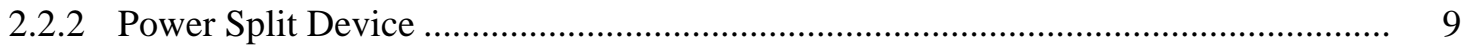

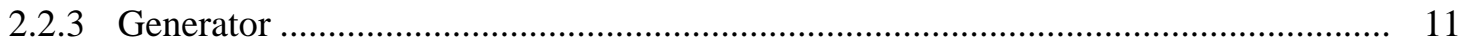

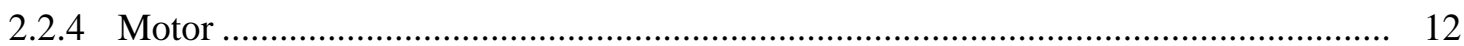

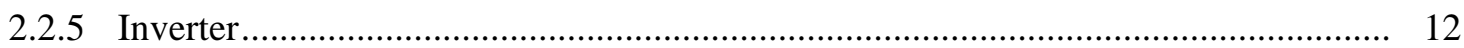

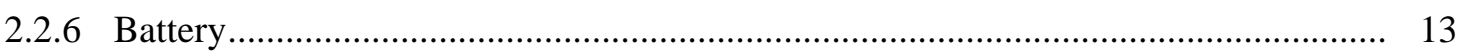

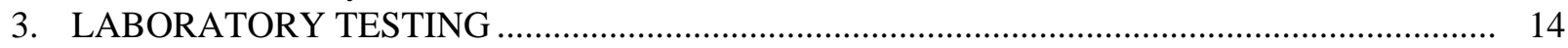

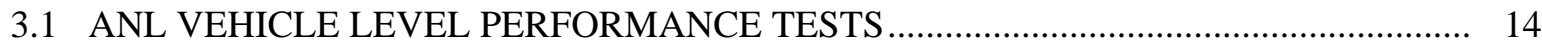

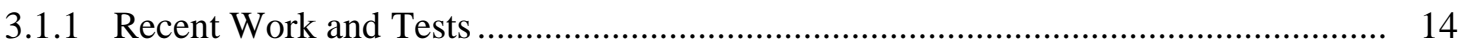

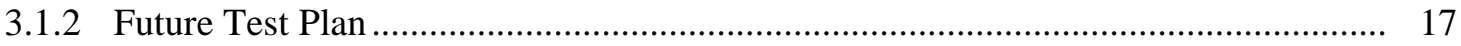

3.2 ORNL COMPONENT-LEVEL PERFORMANCE AND VALIDATION TESTS.............. 17

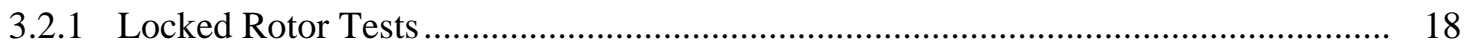

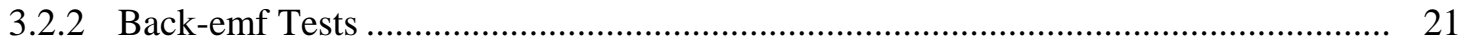

3.2.2.1 Motor Tests ....................................................................................... 21

3.2.2.2 Generator Tests ................................................................................. 22

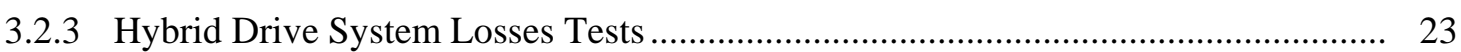

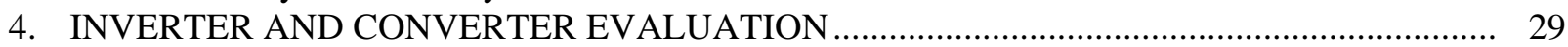

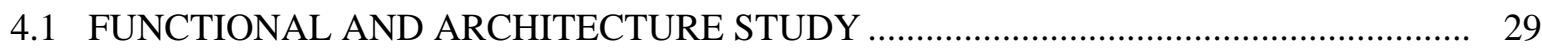

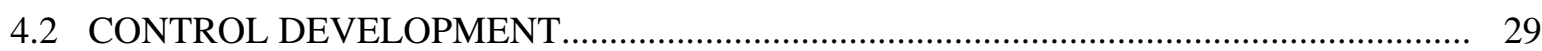

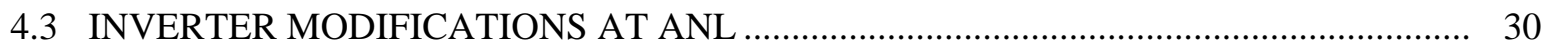

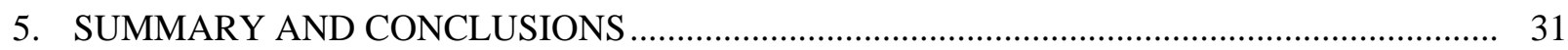

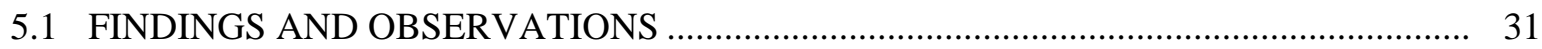

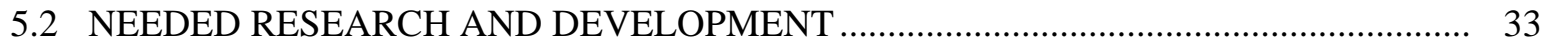

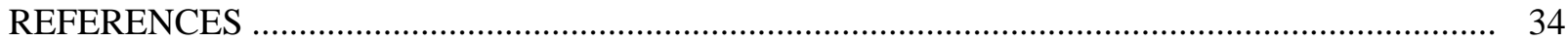




\section{LIST OF FIGURES}

Figure

Page

2.1 Component arrangement for the THS II....................................................................... 5

$2.2 \quad 2004$ Prius engine and hybrid drive assembly ................................................................... 6

2.3 Heat removal and lubrication scheme for the 2004 Prius hybrid electric

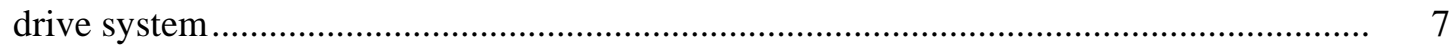

2.4 Diagram of the 2004 Prius power split device.............................................................. 9

2.5 Diagram of the 2004 Prius gear train between the motor and wheels ............................... 10

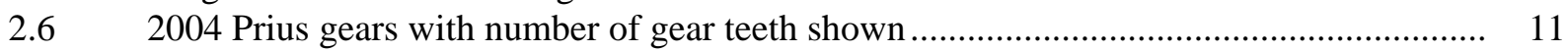

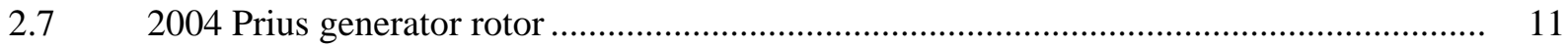

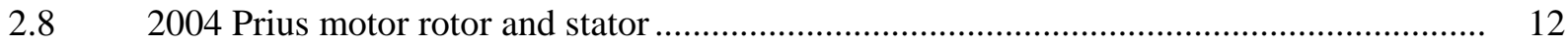

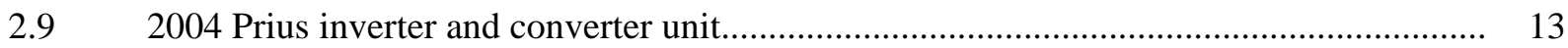

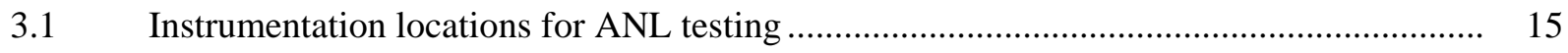

3.2 Sample power measurements under varying speed conditions.......................................... 16

3.3 Sample power measurements under controlled speed conditions....................................... 17

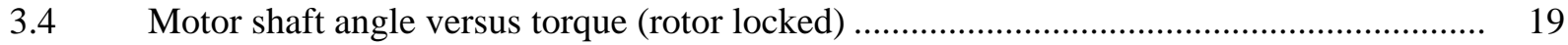

3.5 Locked rotor peak torque as a function of current.......................................................... 19

3.6 Motor back-emf voltage versus motor shaft speed ........................................................ 22

3.7 Generator back-emf voltage versus generator shaft speed ............................................... 23

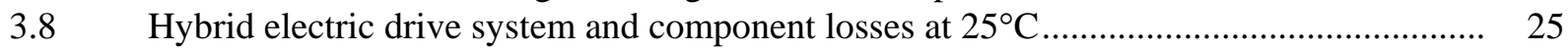

3.9 Configuration B losses as a function of oil temperature................................................ 28 


\section{LIST OF TABLES}

Table

Page

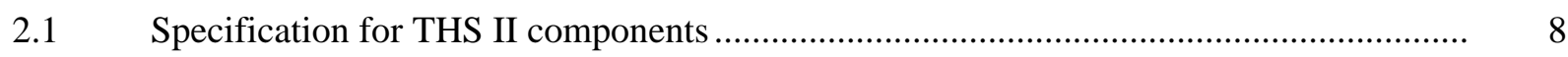

3.1 Measurement variables for ANL testing program ........................................................... 14

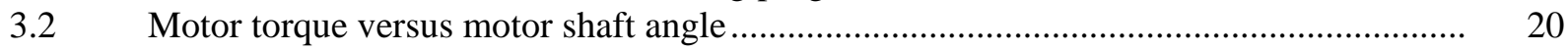

3.3 Test conditions for back-emf voltage measurements...................................................... 21

3.4 Back-emf voltage measurements for the 2004 Prius motor............................................. 21

3.5 Back-emf voltage measurements for the 2004 Prius generator ....................................... 22

3.6 Component configurations for loss determinations .................................................... 23

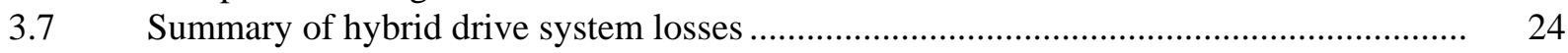

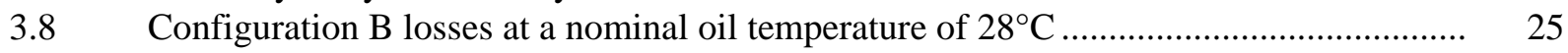

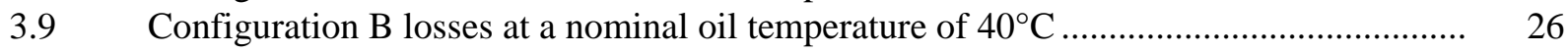

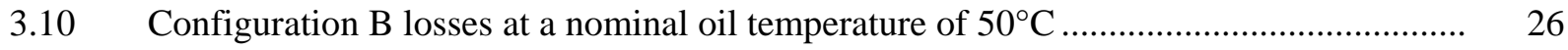

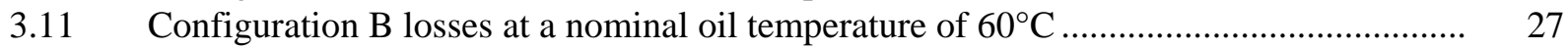

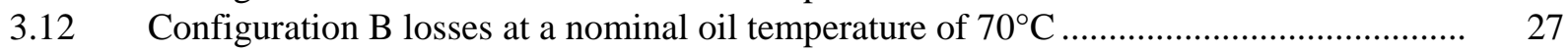

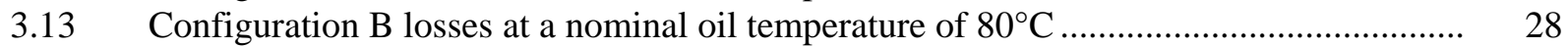

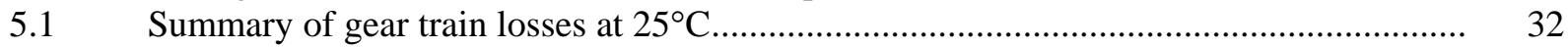

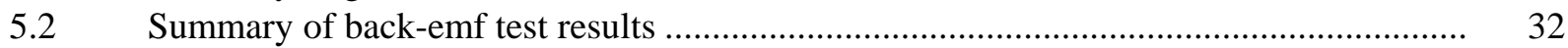

Summary of motor current and torque test results....................................................... 


\section{ACRONYMS}

$\begin{array}{ll}\text { ac } & \text { alternating current } \\ \text { ANL } & \text { Argonne National Laboratory } \\ \text { APRF } & \text { Advanced Powertrain Research Facility } \\ \text { dc } & \text { direct current } \\ \text { DOE } & \text { U.S. Department of Energy } \\ \text { EERE } & \text { Energy Efficiency and Renewable Energy } \\ \text { emf } & \text { electromotive force (measured in volts) } \\ \text { FCVT } & \text { FreedomCar and Vehicle Technologies } \\ \text { GMR } & \text { Giant Magneto Resistive } \\ \text { HEV } & \text { hybrid electric vehicle } \\ \text { km/h } & \text { kilometers per hour } \\ \text { kW } & \text { kilowatt } \\ \text { NTRC } & \text { National Transportation Research Center } \\ \text { Nm } & \text { newton meter } \\ \text { ORNL } & \text { Oak Ridge National Laboratory } \\ \text { PEEMRC } & \text { Power Electronics and Electric Machinery Research Center } \\ \text { PM } & \text { permanent magnet } \\ \text { rms } & \text { root mean square } \\ \text { rpm } & \text { revolutions per minute } \\ \text { THS II } & \text { Toyota Hybrid System (new generation) } \\ \text { W } & \text { watts }\end{array}$




\section{ACKNOWLEDGMENTS}

Preparation of this report was sponsored by the U.S. Department of Energy, Office of Energy Efficiency and Renewable Energy through its FreedomCar and Vehicle Technologies Program. Special thanks are given to Susan Rogers of the Vehicle Systems Technologies subprogram for authorizing this work and overseeing its development. Don Adams of the Oak Ridge National Laboratory is also acknowledged for his overall contribution and guidance for the project. 


\begin{abstract}
Laboratory tests were conducted to evaluate the electrical and mechanical performance of the 2004 Toyota Prius and its hybrid electric drive system. As a hybrid vehicle, the 2004 Prius uses both a gasoline-powered internal combustion engine and a battery-powered electric motor as motive power sources. Innovative algorithms for combining these two power sources results in improved fuel efficiency and reduced emissions compared to traditional automobiles.

Initial objectives of the laboratory tests were to measure motor and generator back-electromotive force (emf) voltages and determine gearbox-related power losses over a specified range of shaft speeds and lubricating oil temperatures. Follow-on work will involve additional performance testing of the motor, generator, and inverter. Information contained in this interim report summarizes the test results obtained to date, describes preliminary conclusions and findings, and identifies additional areas for further study.
\end{abstract}

\title{
1. INTRODUCTION
}

The 2004 Toyota Prius is a hybrid automobile equipped with a gasoline engine and a battery-powered electric motor. Both of these motive power sources are capable of providing mechanical drive power for the vehicle. The engine can deliver a peak power output of 57 kilowatts (kW) at 5000 revolutions per minute (rpm) while the motor can deliver a peak power output of $50 \mathrm{~kW}$ at $1300 \mathrm{rpm}$. Together, this engine-motor combination has a specified peak power output of $82 \mathrm{~kW}$ at a vehicle speed of 85 kilometers per hour $(\mathrm{km} / \mathrm{h})$. In operation, the 2004 Prius exhibits superior fuel economy compared to conventionally powered automobiles.

To acquire knowledge and thereby improve understanding of the propulsion technology used in the 2004 Prius, laboratory tests were conducted to evaluate the electrical and mechanical characteristics of the 2004 Prius and its hybrid electric drive system. This testing was undertaken by the Oak Ridge National Laboratory (ORNL) as part of the U.S. Department of Energy (DOE) - Energy Efficiency and Renewable Energy (EERE) FreedomCar and Vehicle Technologies (FCVT) Program through its vehicle systems technologies subprogram.

\subsection{PROGRAM OVERVIEW}

The Hybrid Electric Vehicle (HEV) program officially began in 1993 as a five-year cost-shared partnership between DOE and American auto manufacturers: General Motors, Ford, and DaimlerChrysler. They committed to produce production-feasible HEV propulsion systems by 1998, first-generation prototypes by 2000, and market-ready HEVs by 2003.

Currently, HEV research and development is conducted by DOE through its FCVT Program. The mission of the FCVT program is to develop more energy efficient and environmentally friendly highway transportation technologies. Program activities include research, development, demonstration, testing, technology validation, and technology transfer. These activities are aimed at developing technologies that can be domestically produced in a clean and cost-competitive manner.

The vehicle systems technologies subprogram, which is one of four subprograms under the FCVT program, supports the efforts of the FreedomCAR through a three-phase approach intended to: 
- Identify overall propulsion and vehicle-related needs by analyzing programmatic goals and reviewing industry's recommendations and requirements, then develop the appropriate technical targets for systems, subsystems, and component research and development activities;

- Develop and validate individual subsystems and components, including electric motors, emission control devices, battery systems, power electronics, accessories, and devices to reduce parasitic losses; and

- Determine how well the components and subsystems work together in a vehicle environment or as a complete propulsion system and whether the efficiency and performance targets at the vehicle level have been achieved.

Source: http://www.eere.energy.gov/vehiclesandfuels/technologies/systems/index.shtml

The research performed under the Vehicle Systems subprogram will help remove technical and cost barriers to enable technology for use in such advanced vehicles as hybrid and fuel-cell-powered vehicles.

\subsection{TESTING FACILITIES}

Evaluation of the 2004 Prius and its hybrid electric drive system involved both vehicle-level and component-level performance testing. Vehicle-level testing is being conducted at the Advanced Powertrain Research Facility (APRF) located at the Argonne National Laboratory (ANL), 9700 S. Cass Avenue, Argonne, Illinois. The APRF is a multi-dynamometer vehicle test facility capable of testing conventional and hybrid vehicle propulsion systems and vehicles. Component-level testing is being conducted by ORNL at its Power Electronics and Electric Machinery Research Center (PEEMRC). The PEEMRC is a broad-based research center for power electronic inverters and electric machinery (motor) development. Located in the recently constructed National User Facility known as the National Transportation Research Center (NTRC), the PEEMRC has more than 9000 square feet of space for developing and building the next generation prototypes of inverters, rectifiers, and electric machine technology.

\subsection{SCOPE AND OBJECTIVE}

This interim report summarizes vehicle-level and component-level test results obtained to date for the 2004 Prius and various electrical and mechanical components of its hybrid electric drive system. The primary objective of these tests was to characterize the electrical and mechanical performance of the 2004 Prius.

Information about the 2004 Prius and its technical design features are presented in Chapter 2 to serve as a foundation for subsequent discussions about the various components of the hybrid electric drive system that were tested. Laboratory test results are summarized in Chapter 3. They include electrical and mechanical data that have been acquired to date at ANL and ORNL. The objectives of these tests were to characterize the functional performance of the hybrid electric drive system and to understand the design methodology used in the construction of the various system components - specifically the generator, traction motor, and inverter. Information about the inverter and converter is presented in Chapter 4. This information includes discussions about the functional characteristics and control development for the inverter and converter and a description of inverter modifications that will provide a way to measure current and voltage values at specific locations. Preliminary conclusions and findings based on the acquired test data along with areas of needed research and development are presented in Chapter 5. 


\subsection{APPROACH}

Complementary electrical and mechanical data from vehicle-level and component-level tests were acquired to gain a full understanding of the 2004 Prius performance. These data were then used to determine back-emf voltage and energy loss values over the specified operating range of the vehicle.

Vehicle-level tests are being performed at the APRF with the electrical and mechanical systems installed in the original factory configuration. The inverter, motor, generator, axles, and related components are instrumented to acquire power flow data needed to characterize vehicle performance.

Component-level tests are being performed at the NTRC by removing the hybrid electric drive system and inverter from the vehicle and mechanically connecting the shaft to a dynamometer. This arrangement also requires a reconfiguration of the inverter so that it will operate outside the vehicle. Using this approach makes it possible to separately evaluate the performance of each power-related component of the hybrid electric drive system. Component-level test results provide data needed to characterize the overall performance of the 2004 Prius. 


\section{HYBRID ELECTRIC DRIVE SYSTEM DESCRIPTION}

The 2004 Prius is a new-generation hybrid automobile that was introduced into the market in September 2003 by the Toyota Motor Corporation. As a hybrid vehicle, the 2004 Prius uses both a gasoline-powered internal combustion engine capable of delivering a peak power output of $57 \mathrm{~kW}$ and a battery-powered electric motor capable of delivering a peak power output of $50 \mathrm{~kW}$ as motive power sources. Combining these two-motive power sources results in improved fuel efficiency and reduced emissions compared to traditional automobiles and provides the 2004 Prius with the following energysaving characteristics.

- Energy-loss reduction is achieved by automatically stopping the engine when idling.

- Energy is recovered and reused by capturing kinetic energy that is normally wasted as heat during deceleration and braking. The starter and electric motor then convert this energy to electricity for use.

- Engine is able to operate at peak efficiency speed a high percentage of the time.

- Supplementary power is provided by the electric motor during acceleration when engine efficiency is low.

- Optimal vehicle efficiency is realized by using the electric motor to run the vehicle under operating conditions when engine efficiency is low and by generating electricity when engine efficiency is high.

Enhanced performance of the 2004 Prius is attributed to the new-generation Toyota Hybrid System (THS II). This system is a power train consisting of a high-power motor, generator, and a battery of relatively low power. Major components of the THS II are shown in Fig. 2.1. As this figure indicates, a mechanical component referred to as a power split device (planetary gear set) separates power supplied by the gasoline engine into two paths. In the mechanical path, engine power is transmitted to the vehicle's wheels directly through the transmission. In the electrical path, a generator converts mechanical energy from the engine into electrical energy. Electricity produced by the generator is then available for either supplementing the battery power to the electric motor or charging the battery, or both. By using energy in this manner, the 2004 Prius requires no external power source for battery charging. The power split device allows the engine to function at or near its optimal operating speed, regardless of vehicle speed, while still being able to efficiently add power to the wheels and simultaneously drive the generator. A photograph of the engine and hybrid drive assembly after removal from the car is shown in Fig. 2.2.

In operation, the 2004 Prius is capable of functioning in the following modes:

- When engine efficiency is low, such as during start-up and mid-range speeds, motive power is provided by the motor alone using energy stored in the battery.

- Under normal driving conditions, overall efficiency is optimized by controlling the power allocation so that some of the engine power is used for turning the generator to supply electricity for the motor while the remaining power is used for turning the wheels.

- During periods of acceleration when extra power is needed, the generator supplements the electricity being drawn from the battery so the motor is supplied with the required level of electrical energy. 
- While decelerating and braking, the motor acts as a generator that is driven by the wheels thus allowing the recovery of kinetic energy. The recovered kinetic energy is converted to electrical energy that is stored in the battery.

- When necessary, the generator recharges the battery to maintain sufficient reserves.

- At times when the vehicle is not moving and when the engine moves outside of certain speed and load conditions, the engine stops automatically.

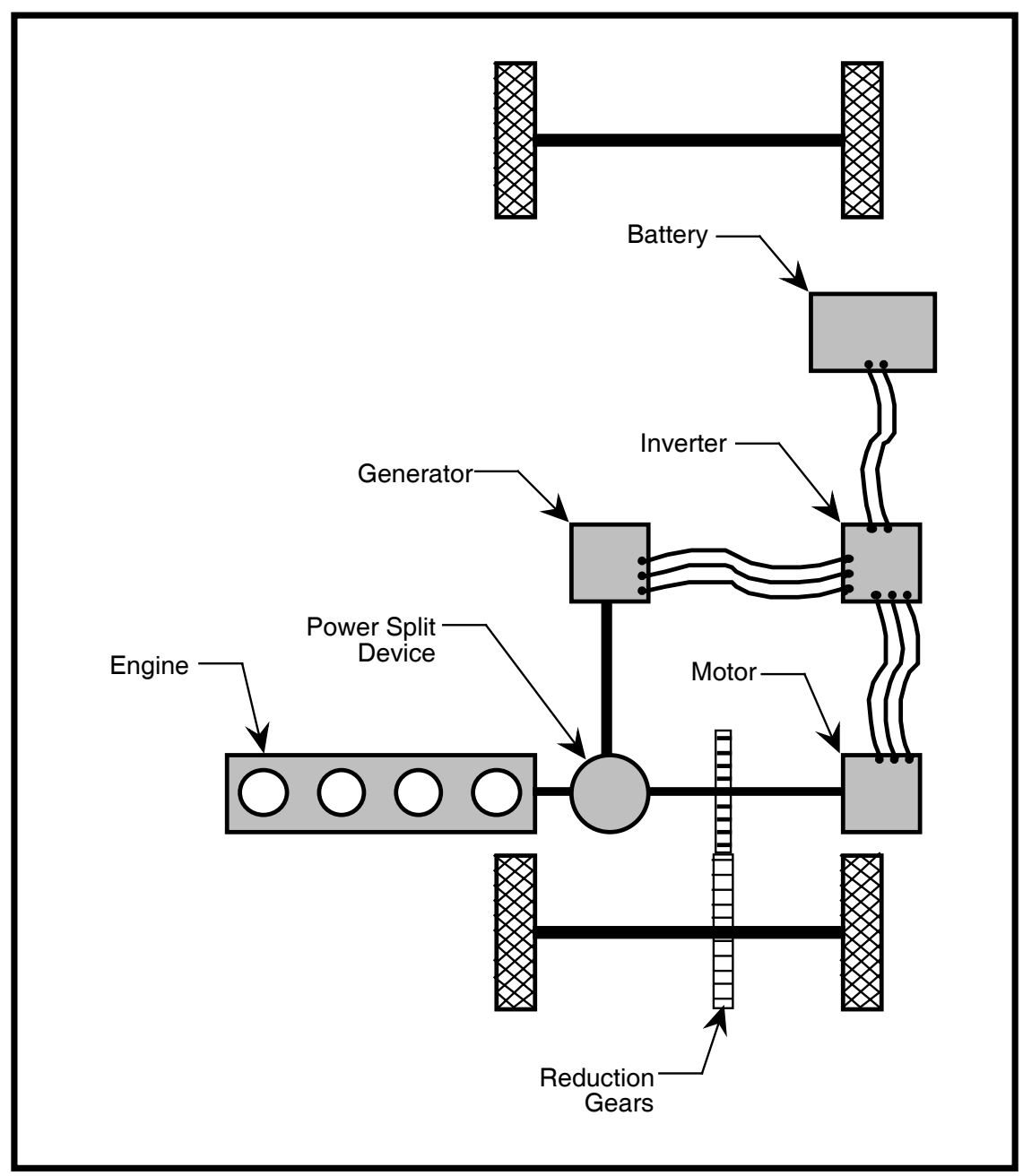

Fig. 2.1. Component arrangement for the THS II. 


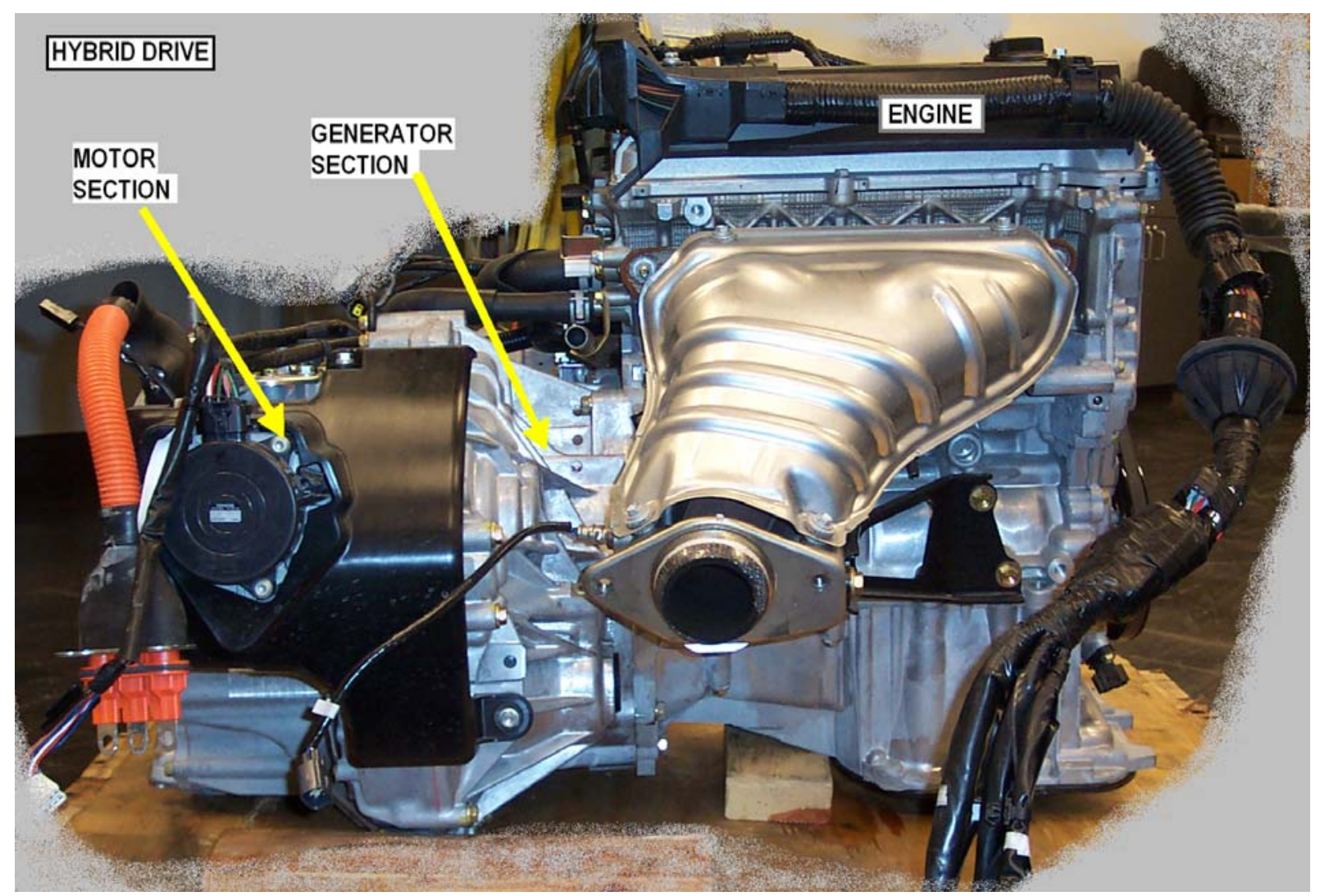

Fig. 2.2. 2004 Prius engine and hybrid drive assembly.

Additional information about the capabilities and properties of the 2004 Prius are presented in a separate ORNL report. ${ }^{1}$

To maintain the operating temperature of the various system components within an acceptable range, the 2004 Prius has two separate ethylene glycol based coolant systems. The arrangements of these coolant systems and a brief description of their functional characteristics are presented in Fig. 2.3.

The engine coolant system is similar to the coolant system in a traditional automobile. Its purpose is to circulate a liquid coolant through the engine to remove excess thermal energy generated by fuel combustion. A pump forces the coolant to flow from the engine to a radiator where the waste heat is dumped. To keep the coolant from escaping, the coolant is confined in a closed loop that is protected from over pressurization by a self-closing pressure relief valve (radiator cap). This valve vents at a pressure that is slightly above atmospheric pressure thereby allowing the coolant to remain liquid at a temperature slightly above the boiling point of water. To accommodate changes in coolant volume caused by temperature and pressure fluctuations, the system includes a tank that functions as an overflow reservoir. The engine coolant system also includes an insulated coolant storage bottle that stores hot coolant during shutdown and makes it available when the engine is restarted. Using hot coolant in this way reduces exhaust gas emissions produced during cold-engine startup. 


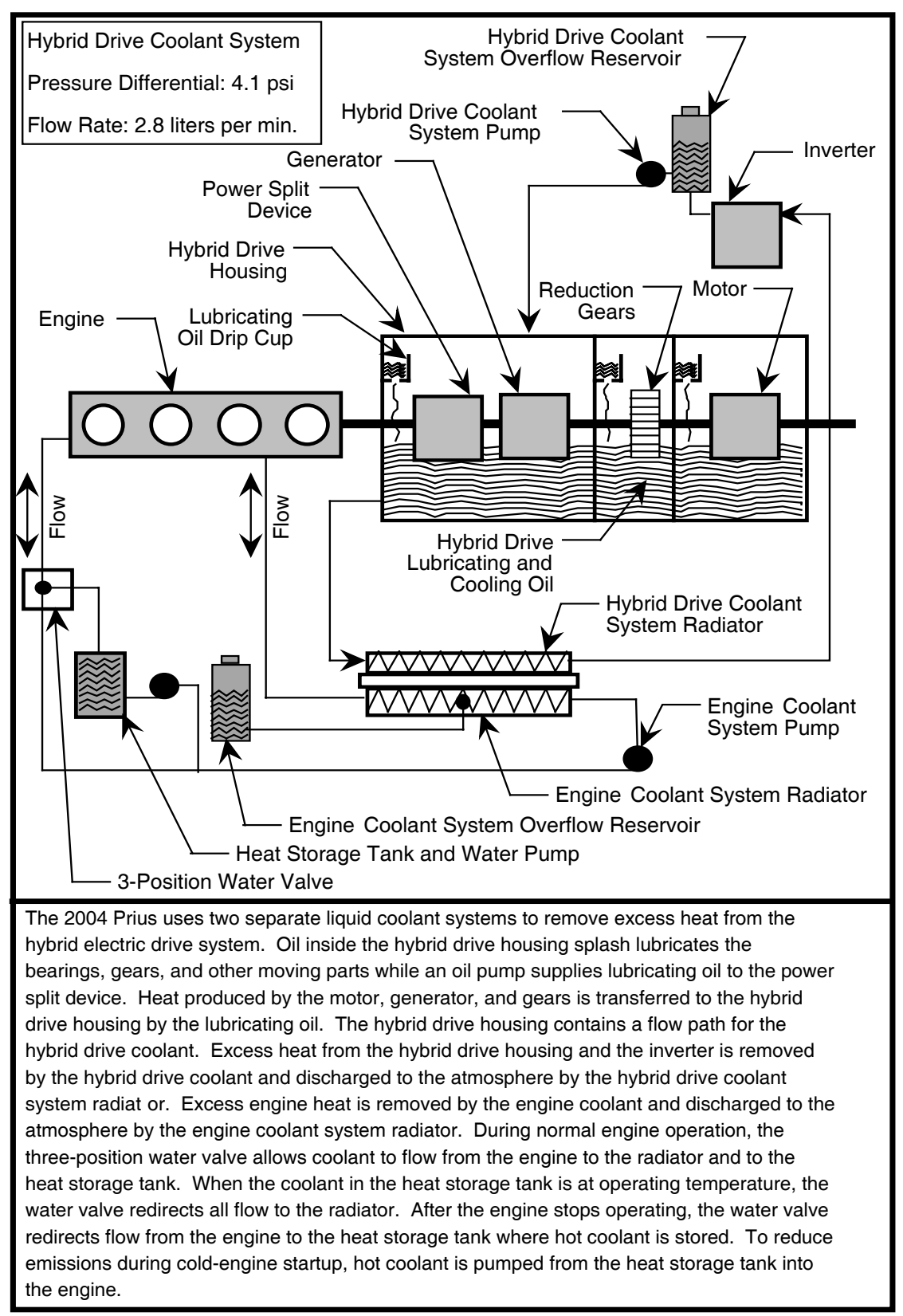

Fig. 2.3. Heat removal and lubrication scheme for the 2004 Prius hybrid electric drive system.

The hybrid drive coolant system is separate from the engine coolant system because the two systems operate at different temperatures ${ }^{\dagger}$. Powered by an electric pump, the liquid coolant in this closed-loop system flows continuously through the motor, generator, inverter, and radiator. Heat removed from these electrical components is transferred to the surrounding atmosphere by the radiator. Like the engine coolant system, the hybrid coolant system also includes a tank that functions as an overflow reservoir.

Detailed information about the 2004 Prius and its operation and maintenance is provided in the threevolume repair manual published by the Toyota Motor Corportaion., ${ }^{2,3}$

\footnotetext{
${ }^{\dagger}$ Although the reason for using two separate coolant systems cannot be confirmed, it is believed that this decision was made to allow the motor, generator, and inverter to operate well below $100^{\circ} \mathrm{C}$, the boiling point of water.
} 


\subsection{DESIGN REQUIREMENTS}

The high-voltage power circuit in the THS II, which includes the motor and generator, is designed to operate over a variable voltage range of 200 to $500 \mathrm{Vdc}$. This elevated-voltage design feature results in an increase in efficiency because electrical power can be supplied to the motor using a smaller current. In addition, the elevated voltage allows the motor to operate at higher speeds where high back emf would inhibit the speed of a lower voltage motor.

\subsection{SYSTEM COMPONENTS}

Major THS II components in the 2004 Prius include the

- engine,

- power split device,

- generator,

- motor,

- inverter, and

- battery.

The specification for these components is shown in Table 2.1.

Table 2.1. Specification for THS II components

\begin{tabular}{cll}
\hline Component & \multicolumn{1}{c}{ Property description } & \multicolumn{1}{c}{ Property value } \\
\hline \multirow{2}{*}{ Engine } & Type & 1.5 liter gasoline (high-expansion ratio cycle) \\
& Maximum output & $57 \mathrm{~kW}$ at $5000 \mathrm{rpm}$ \\
& Maximum torque & $115 \mathrm{Newton}$ meter $(\mathrm{Nm})$ at $4200 \mathrm{rpm}$ \\
\hline \multirow{2}{*}{ Motor } & Type & Synchronous ac permanent magnet (PM) \\
& Maximum output & motor \\
& Maximum torque & $50 \mathrm{~kW}$ between 1200 and $1540 \mathrm{rpm}$ \\
\multirow{2}{*}{ System* } & Maximum output & $400 \mathrm{Nm}$ between 0 and $1540 \mathrm{rpm}$ \\
& Maximum torque at $22 \mathrm{~km} / \mathrm{h}$ or & $82 \mathrm{~kW}$ at $85 \mathrm{~km} / \mathrm{h}$ and higher \\
& lower & $478 \mathrm{Nm}$ \\
\hline \multirow{2}{*}{ Battery } & Type & Nickel-metal hydride \\
& Construction & $28 \mathrm{each} 7.2 \mathrm{~V}$ modules connected in series \\
& Voltage & $201.6 \mathrm{~V}$ \\
& Power output & $21 \mathrm{~kW}$ \\
\hline
\end{tabular}

*Maximum combined engine and hybrid battery output and torque constantly available within a specified vehicle speed range.

Sources: http://www.toyota.co.jp/en/tech/environment/ths2/, http://www.toyota.com/vehicles/2005/prius/specs.html

\subsubsection{Engine}

The design of the 1.5-liter engine in the 2004 Prius is based on the Atkinson Cycle in which compression stroke and expansion stroke duration can be set independently. A supercharger is used with the engine to increase its output. 


\subsubsection{Power Split Device}

Major transmission components in the THS II include the power split device (planetary gear set), the generator, the electric motor, and the reduction gears. The purpose for the power split device is to allow power from the engine to turn the generator and the wheels, simultaneously. In operation, shaft power from the engine is transmitted via the planetary carrier. The rotational shaft of the planetary carrier inside the gear mechanism is directly linked to the engine and transmits the motive power to the outer ring gear and the inner sun gear via pinion gears. The rotating shaft of the ring gear is directly linked to the motor and transmits traction drive force while the rotating shaft of the sun gear is directly linked to the generator. Diagrams of the power split device and the gear train that connect the motor to the front wheels are shown in Figs. 2.4 and 2.5, respectively. The actual gear arrangement is shown in Fig. 2.6.

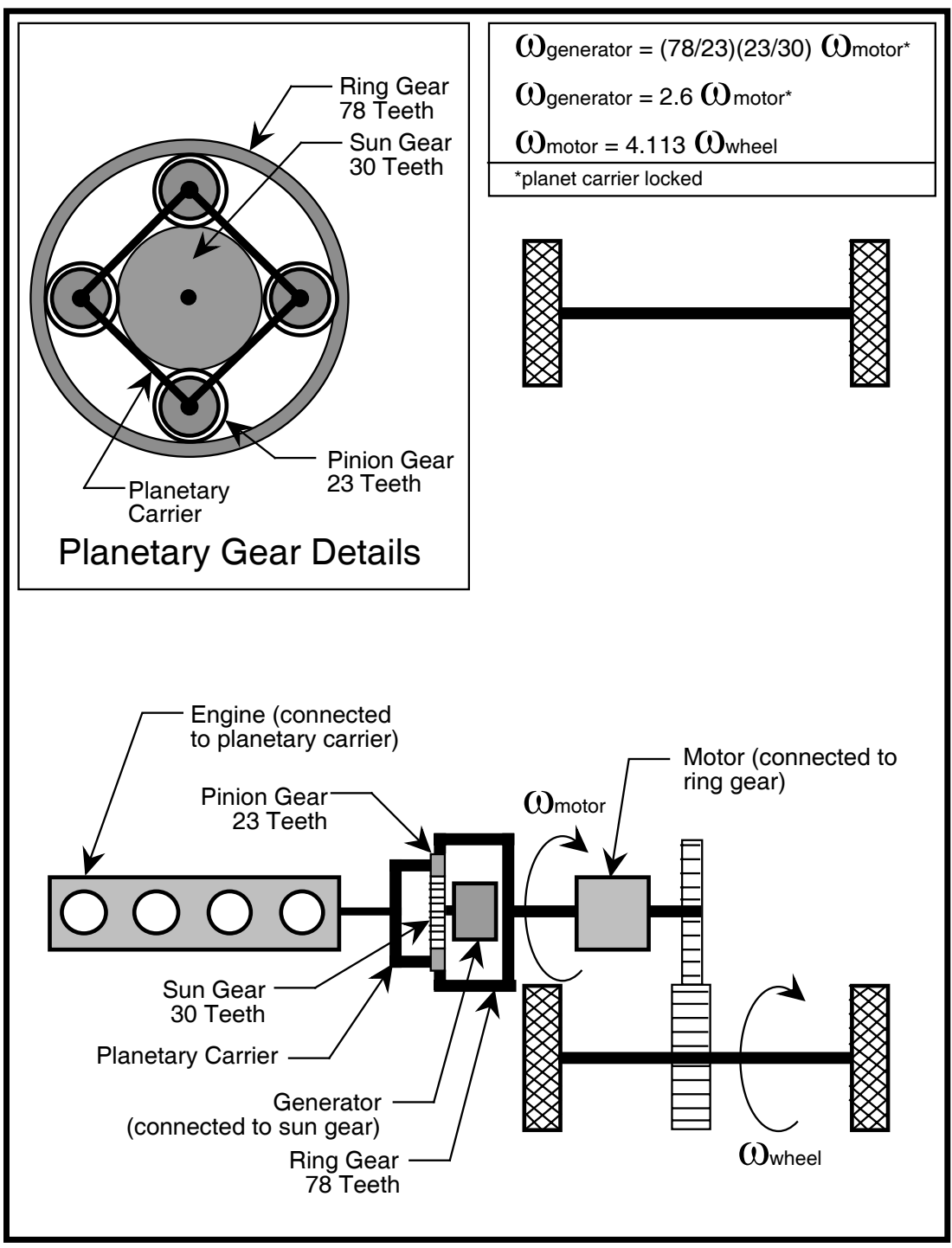

Fig. 2.4. Diagram of the 2004 Prius power split device. 


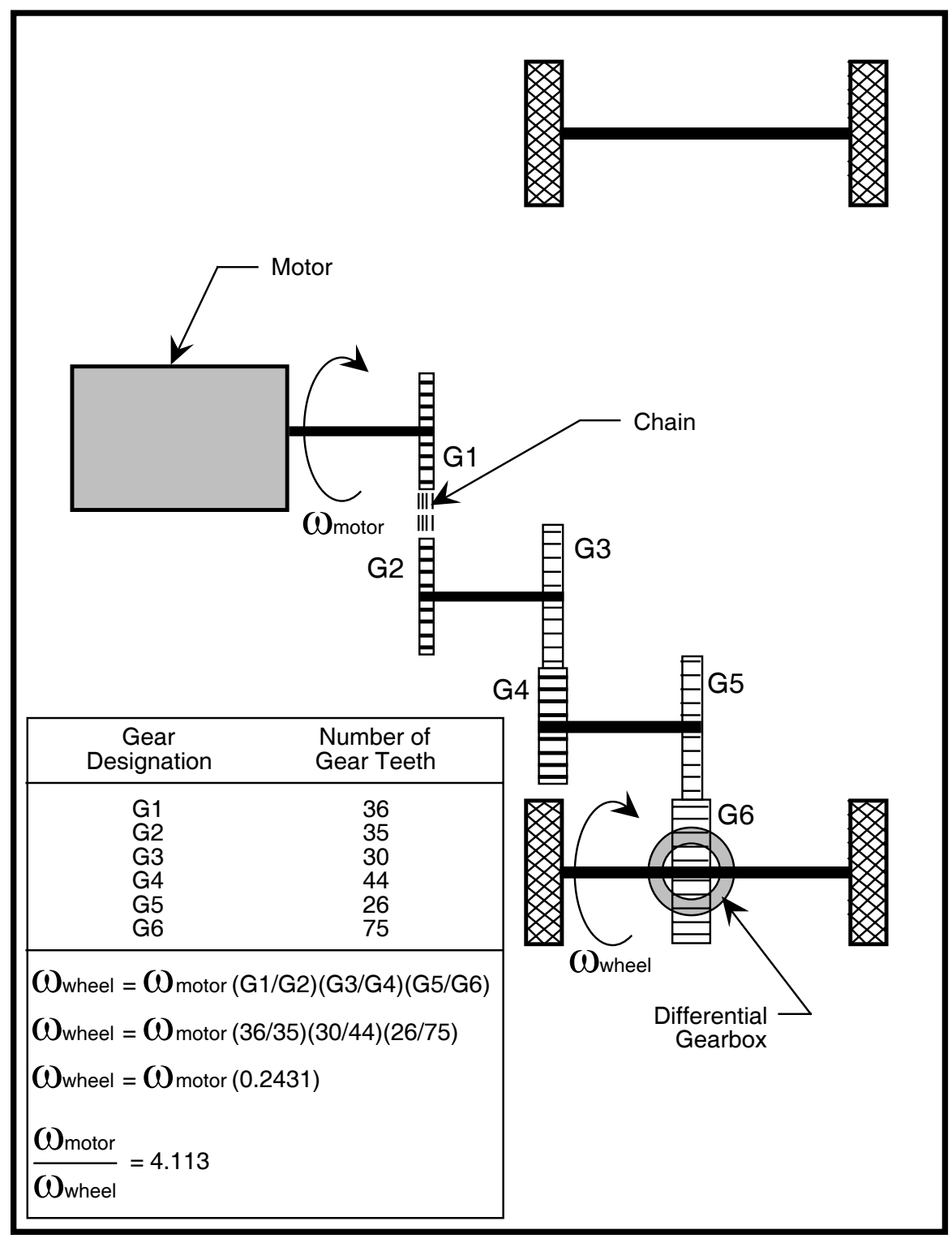

Fig. 2.5. Diagram of the 2004 Prius gear train between the motor and wheels. 


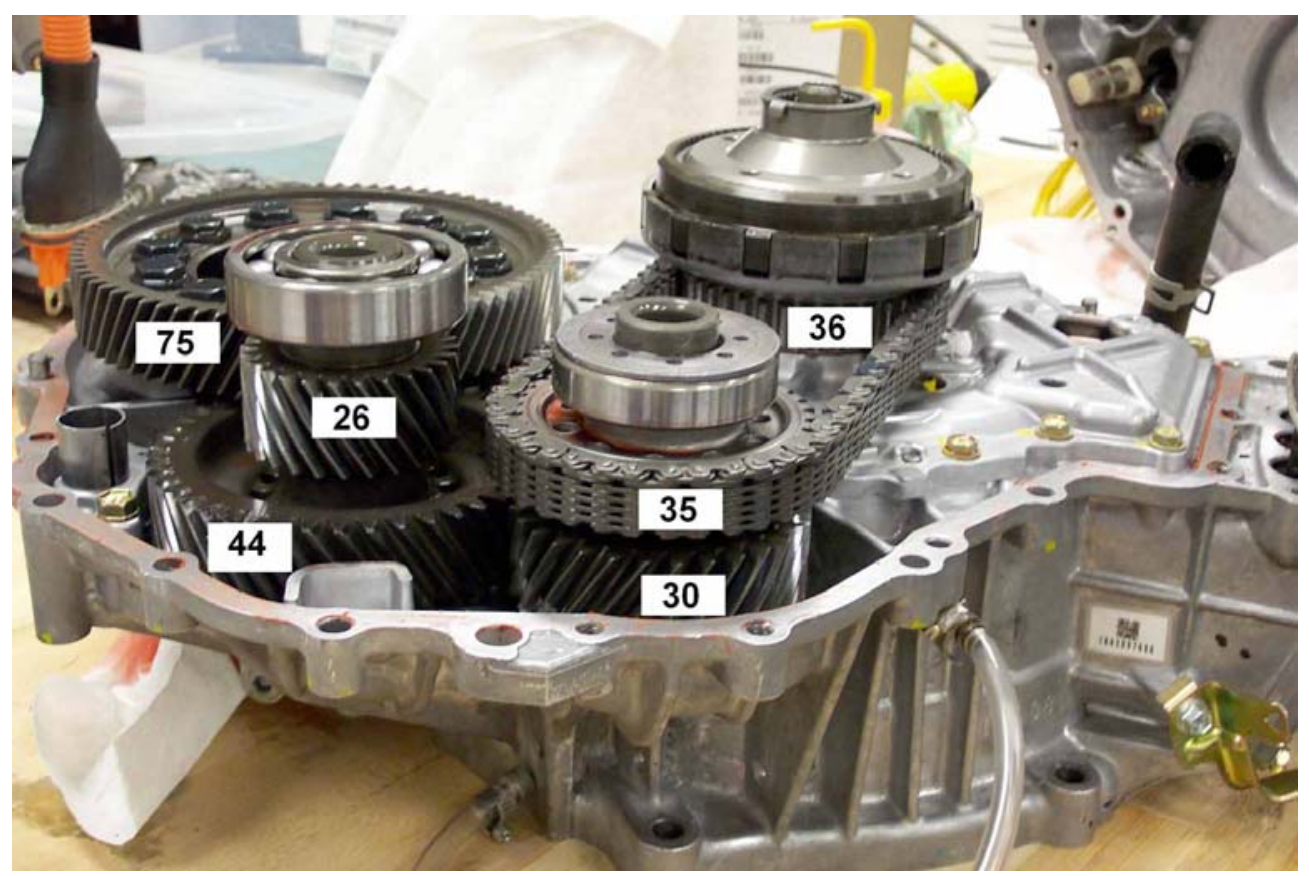

Fig. 2.6. 2004 Prius gears with number of gear teeth shown.

\subsubsection{Generator}

The THS II includes a synchronous-type alternating current (ac) generator that rotates at high speeds up to 10,000 rpm. By rotating at high speeds, the generator, which is an 8-pole PM device, provides highpower density for charging the battery and supplementing motor power requirements. In addition, the generator also functions as the engine starter. At start up, the generator rotates the sun gear in the power split device and thereby provides cranking power for the engine. The configuration of the generator rotor is shown in Fig. 2.7.

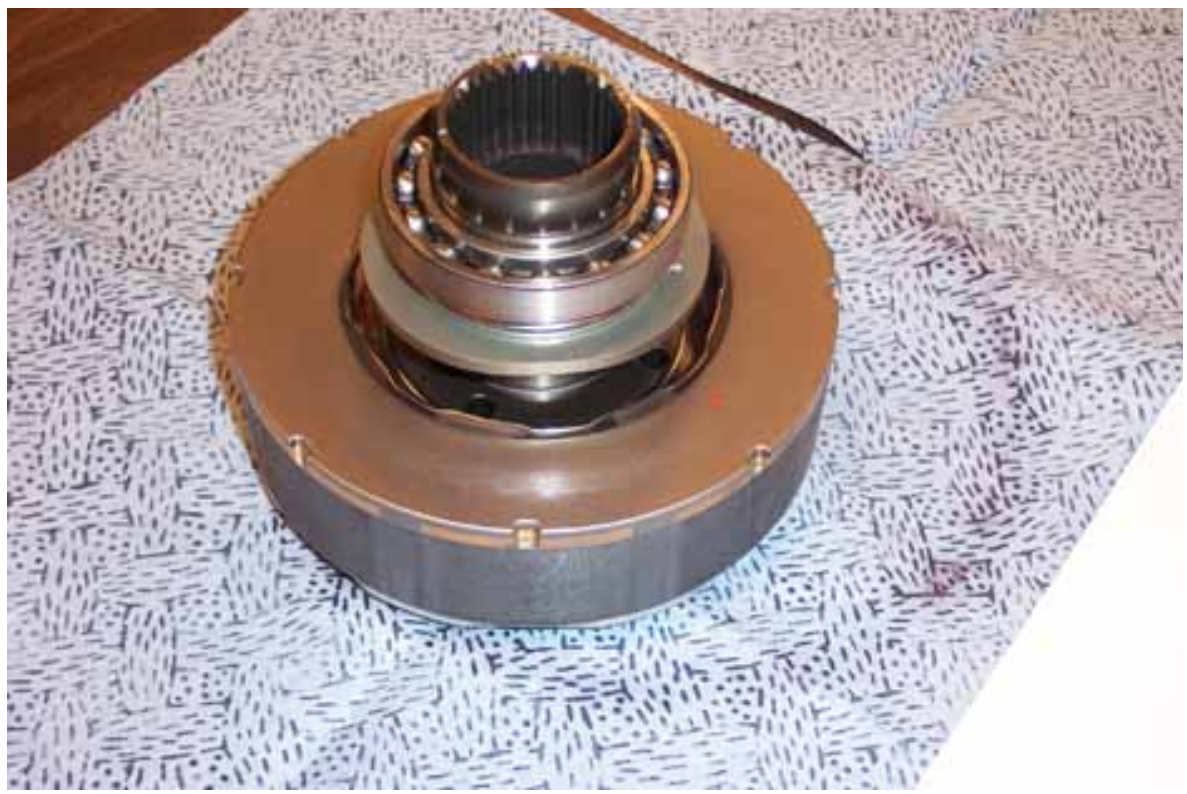

Fig. 2.7. 2004 Prius generator rotor. 


\subsubsection{Motor}

The 8-pole, PM synchronous motor features high low-speed torque and high power output. It is designed as a high-efficiency, direct current (dc) brushless motor that uses ac. The motor rotor is constructed with interior PMs and laminated stacked electromagnetic steel plates. The PMs are arranged in a V-shape as opposed to conventional radial alignment. In addition, with a high supply voltage up to $500 \mathrm{~V}$, the peak power output of the motor is $50 \mathrm{~kW}$. The configuration of the motor and stator are shown in Fig. 2.8. Additional details about the design and manufacture of the motor are contained in a report that was recently published by ORNL. ${ }^{5}$ Supplementary information about locked rotor torque and current performance, which is addressed in Sect. 3.2.1, is contained in another ORNL report. ${ }^{1}$

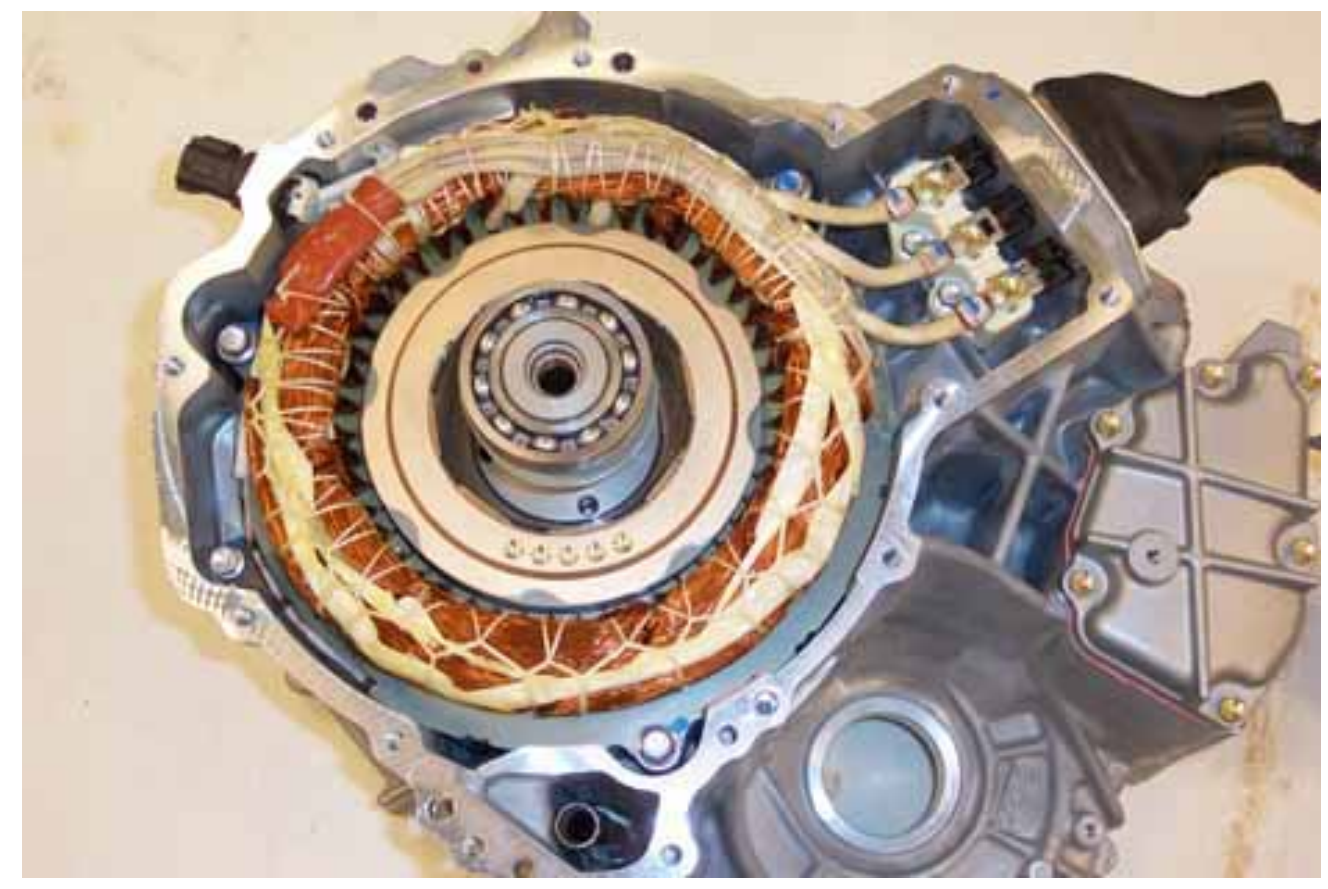

Fig. 2.8. 2004 Prius motor rotor and stator.

\subsubsection{Inverter}

The power control unit consists of the following components

- motor inverter,

- generator inverter,

- buck/boost converter,

- air conditioning compressor inverter, and

- a $12 \mathrm{~V}$ dc-to-dc converter

The unit, which is shown in Fig. 2.9, is capable of converting the dc from the battery into ac for driving the motor and a dc-to-dc converter for conversion to $12 \mathrm{~V}$ for auxiliary equipment. It also includes a highvoltage, bi-directional, dc-to-dc converter that boosts the $200 \mathrm{~V}$ battery up to a maximum of $500 \mathrm{Vdc}$ link, or bucks the higher voltage dc link (that may range from $200 \mathrm{~V}$ to $500 \mathrm{~V}$ ) down to charge the $200 \mathrm{~V}$ battery. 


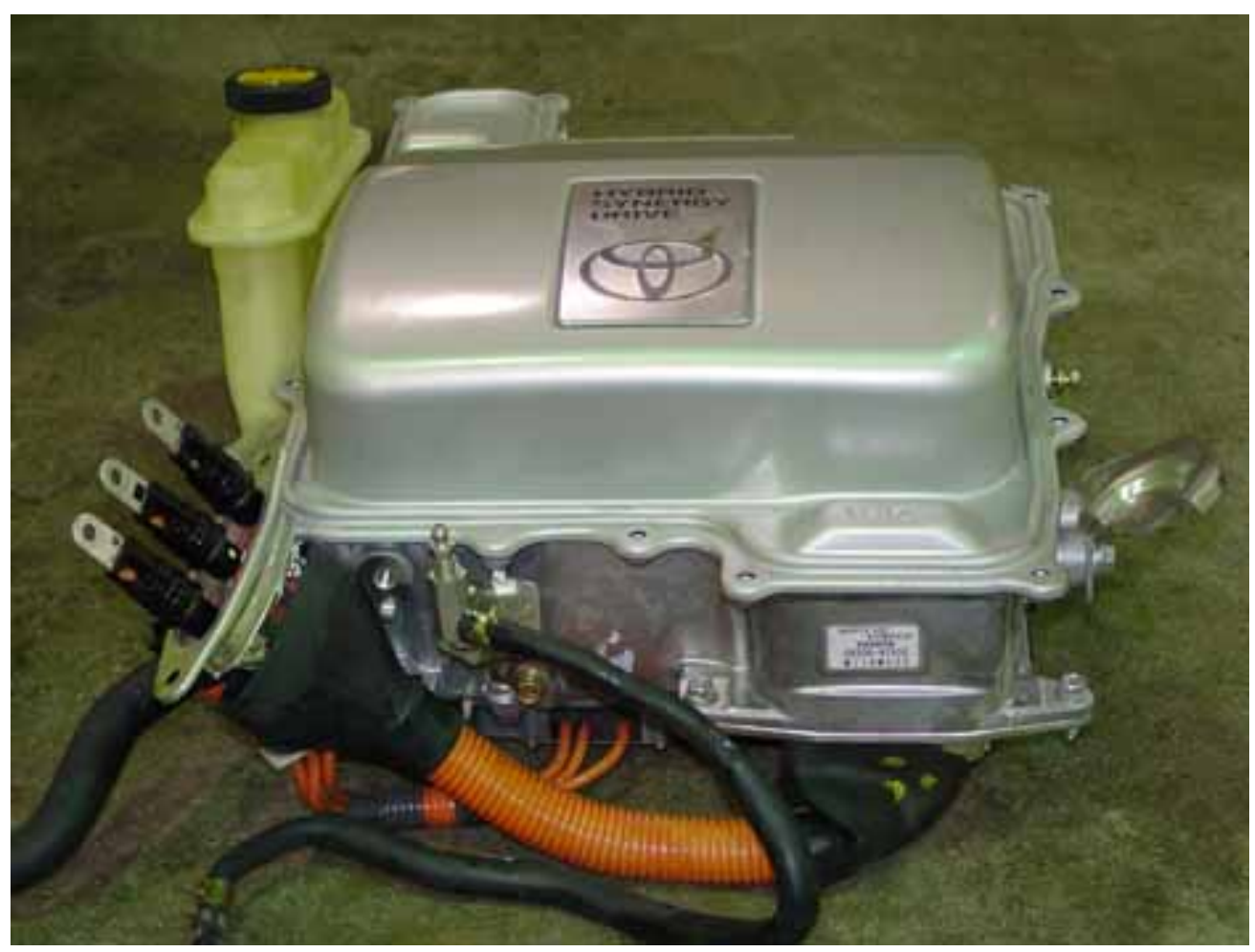

Fig. 2.9. 2004 Prius inverter and converter unit.

\subsubsection{Battery}

A compact, high-performance nickel-metal hydride rechargeable battery is used in the 2004 Prius. The battery consists of 28 low-voltage modules (7.2V each) connected in series to produce a nominal 201.6V. It provides electricity to the motor and receives charging energy from the generator. The specified power output from the battery is $21 \mathrm{~kW}$. 


\section{LABORATORY TESTING}

Laboratory testing of the 2004 Prius hybrid electric drive system and its components is being conducted at ANL and ORNL. The objectives of these testing programs are to characterize the functional performance of the hybrid electric drive system and to understand the design methodology used in the construction of its various components, specifically the generator, traction motor, inverter, and coolant system.

\subsection{ANL VEHICLE-LEVEL PERFORMANCE TESTS}

Beginning in early 2004, a vehicle-level performance-testing program was initiated at ANL. Objectives of this ongoing collaboration are to determine the operating characteristics and to quantify efficiencies of the 2004 Prius hybrid electric drive system as originally installed in the vehicle. The tests are being conducted at its advanced powertrain research facility under both steady state and dynamic conditions. To acquire the necessary electrical data, all accessible power flow points were instrumented to measure voltage and current. Power measurements were obtained between the following locations:

- Generator and inverter (Phase A current, Phase B current, A-C voltage, B-C voltage),

- Traction motor and inverter (Phase A current, Phase B current, A-C voltage, B-C voltage),

- Boost converter and battery (battery current, battery dc voltage), and

- Boost converter to main inverters (dc voltage, current)

Test variables that were measured are identified in Table 3.1.

Table 3.1. Measurement variables for ANL testing program

\begin{tabular}{lcc}
\hline \multicolumn{1}{c}{ Variable description } & Variable designation & Measurement type \\
\hline Generator Power In & $\mathrm{P}_{\text {genAC }}$ & Electrical \\
Motor Power Out (to wheels) & $\mathrm{P}_{\mathrm{mtr}}$ & Mechanical \\
$\begin{array}{l}\text { Inverter Power Out (inverter to } \\
\text { motor) }\end{array}$ & $\mathrm{P}_{\mathrm{mtrAC}}$ & Electrical \\
Boost Power High Side & $\mathrm{P}_{\mathrm{boostHI}}$ & Electrical \\
Battery Power (battery dc link) & $\mathrm{P}_{\mathrm{BATT}}$ & Electrical \\
\hline
\end{tabular}

Each test run was conducted with the air conditioner compressor inverter and the auxiliary $12 \mathrm{~V}$ dc-dc converter disabled. To ensure precise acceleration and speed settings during the tests, the accelerator position was remotely controlled.

\subsubsection{Recent Work and Tests}

The ANL chassis dynamometer is normally setup to monitor vehicle emissions under various driving cycles. Testing of a HEV requires a greater monitoring effort to cover the additional electrical devices incorporated in the vehicle. In addition, the joint ANL and ORNL testing effort requires very precise power measurements to fully characterize 2004 Prius performance. The test setup for the 2004 Prius hybrid electric drive system involves current and voltage measurements at numerous points within the system. Figure 3.1 shows the configuration of the basic electrical components for the 2004 Prius hybrid 
electric drive system and the locations of the installed instrumentation. Details about the ANL inverter modifications are discussed in Sect. 4.3.

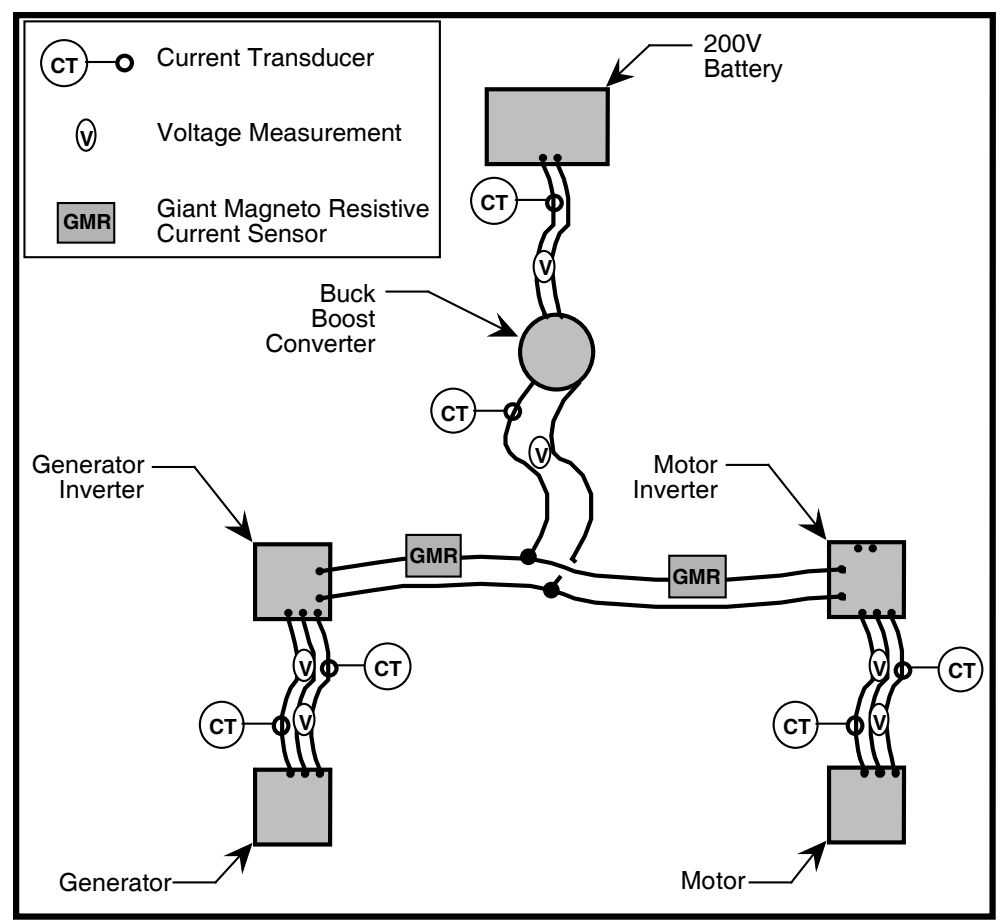

Fig. 3.1. Instrumentation locations for ANL testing.

An example time trace of data being acquired during the tests is presented in Fig. 3.2. It shows the power flow in different parts of the hybrid electric drive system with the vehicle speed overlaid on the graph. Review of this graph reveals that engine power is high when the vehicle is accelerating to higher speeds and drops to zero when the vehicle speed is constant, thus allowing the electric motor to propel the vehicle without assistance from the engine. At the highest speeds, however, the engine and the motor simultaneously supply power for the vehicle. The testing is providing additional data needed to fully characterize vehicle-level performance, but calibration checks are currently being performed on the power sensing equipment to resolve possible offsets and discrepancies in the data.

Another example data plot that illustrates the relationship between battery power, boost converter power, and motor power is shown in Fig. 3.3. This data was acquired under controlled conditions in which all auxiliary equipment was switched off (i.e., air conditioning compressor inverter and $12 \mathrm{~V}$ dc-to-dc converter) so the battery, boost, and motor power levels would be directly related to each other. Boost power is very close to the battery power because boost converters have low losses. Motor electrical power should be approximately the same but slightly lower due to efficiency losses in the motor inverter. Gross efficiencies can be inferred from this data, but more detailed efficiency results are expected as testing continues. Although this graph validates the measurement results, slight discrepancies in the data and others factors indicate the need to verify the sensor calibrations and data acquisition system settings. This verification process has been initiated and will be completed in the near future. 


\section{Toyota Prius THS II \\ ANL Chassis Dynamometer Power Flow Evaluation}

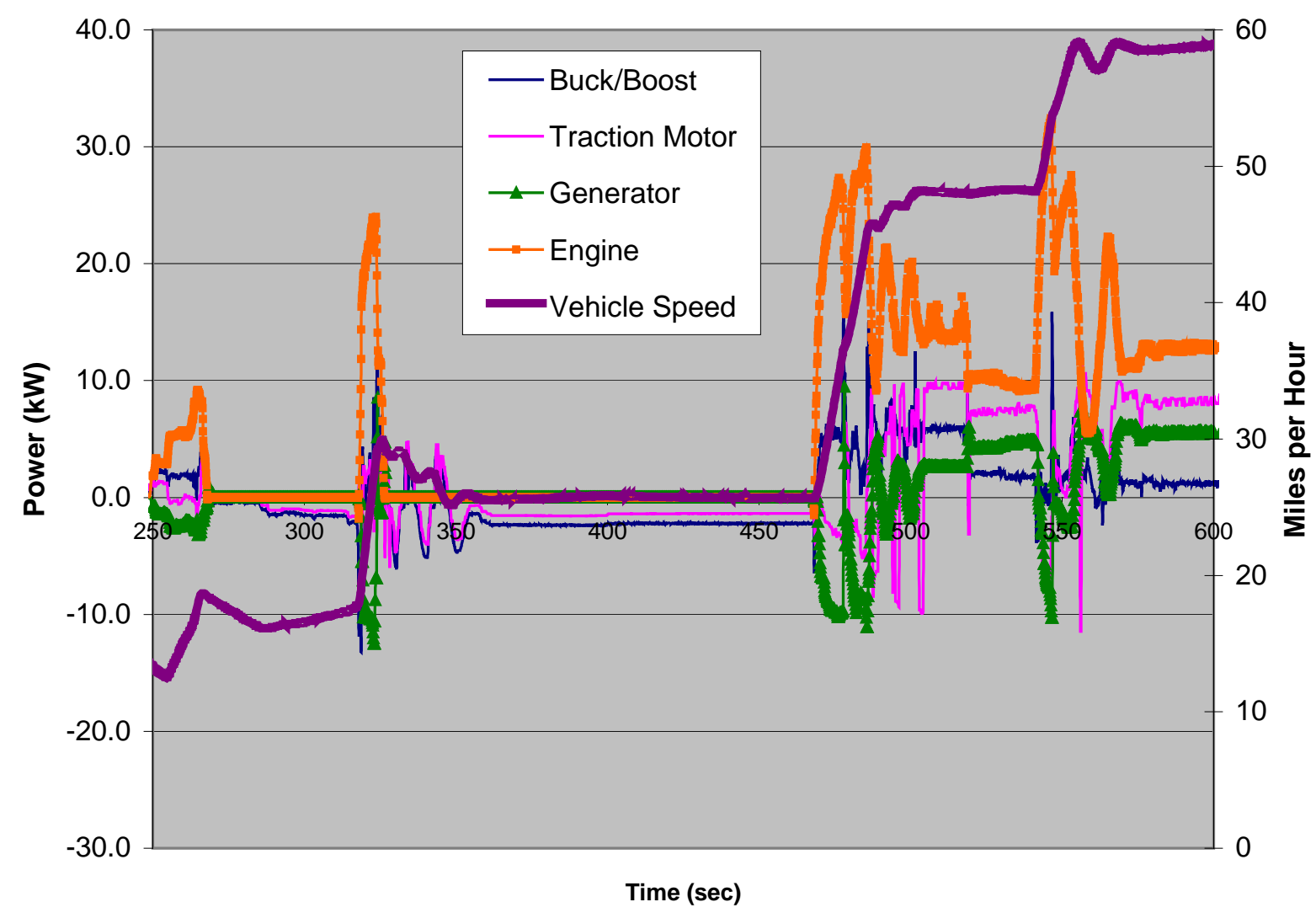

Fig. 3.2. Sample power measurements under varying speed conditions.

Another example data plot that illustrates the relationship between battery power, boost converter power, and motor power is shown in Fig. 3.3. This data was acquired under controlled conditions in which all auxiliary equipment was switched off (i.e. air conditioning compressor inverter and $12 \mathrm{~V}$ dc-to-dc converter) so the battery, boost, and motor power levels would be directly related to each other. Boost power is very close to the battery power because boost converters have low losses. Motor electrical power should be approximately the same but slightly lower due to efficiency losses in the motor inverter. Gross efficiencies can be inferred from this data, but more detailed efficiency results are expected as testing continues. Although this graph validates the measurement results, slight discrepancies in the data and other factors indicate the need to verify the sensor calibrations and data acquisition system settings. This verification process has been initiated and will be completed in the near future. 


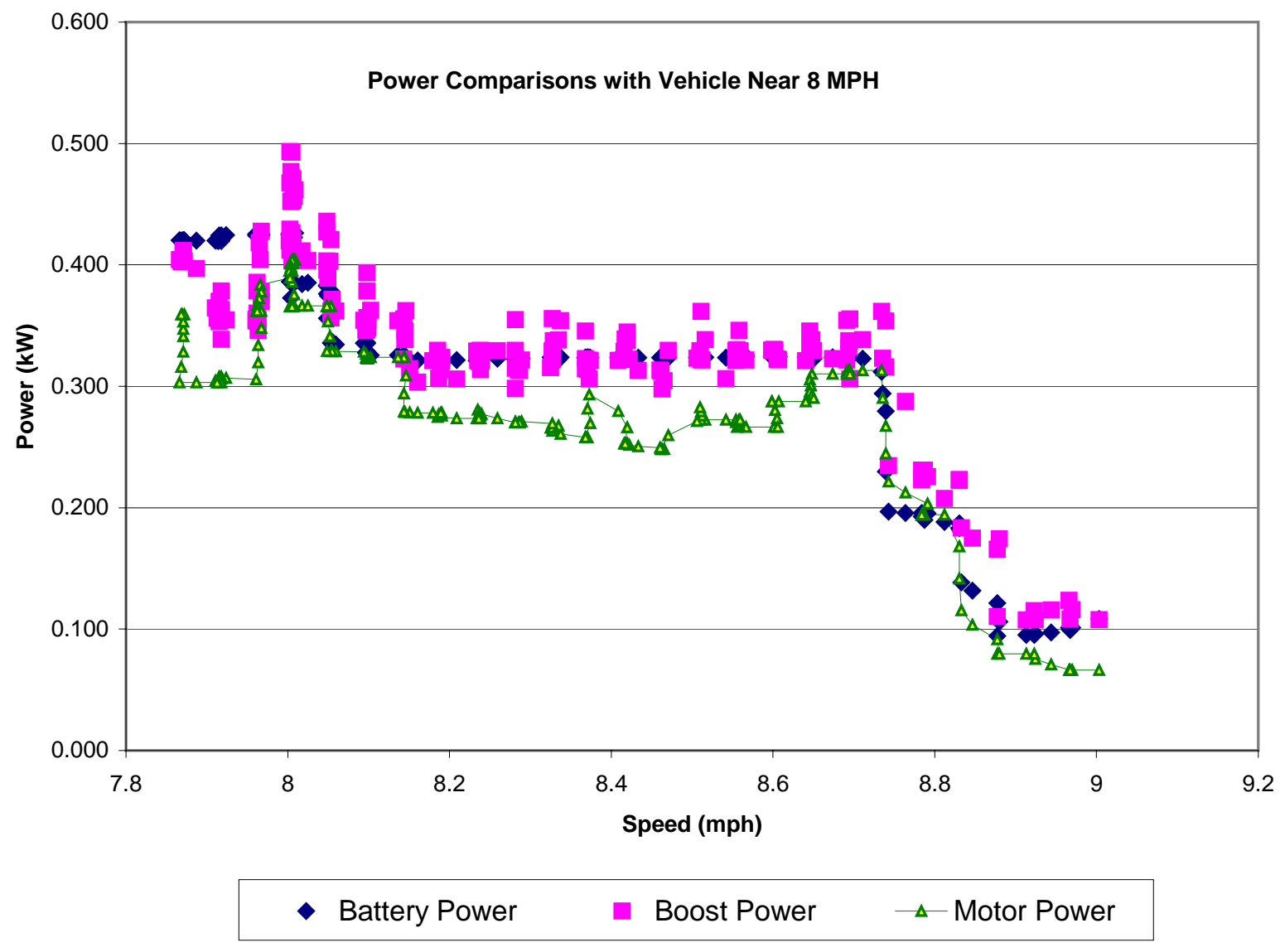

Fig. 3.3. Sample power measurements under controlled speed conditions.

\subsubsection{Future Test Plan}

Future testing at ANL will involve the following additional measurements:

- Boost converter and generator on internal dc link (current, dc voltage), and

- Boost converter and traction motor on internal dc link (current, dc voltage).

In addition, modifications are being made to another inverter-converter unit that will be used in ORNL component-level testing. These modifications are discussed in Sect. 4.3.

\subsection{ORNL COMPONENT-LEVEL PERFORMANCE AND VALIDATION TESTS}

The hybrid electric drive system for the 2004 Prius was also tested at ORNL under a variety of operating conditions to characterize its electrical and mechanical performance. Objectives of the testing program were to measure motor and generator back-emf voltages, evaluate motor starting torque capacity, and determine gearbox-related power losses over a specified range of shaft speeds and lubricating oil temperatures. To eliminate effects of engine friction from the evaluation, the engine was removed from the system during the tests. 
Accomplishing the testing program objectives required connecting the hybrid electric drive system to a dynamometer that was capable of providing the power needed to turn the system components at specified rotational speeds. To ensure that both axles rotated at the same speed, the differential was modified so the internal gears of the differential could not rotate. By blocking rotation of these gears, it was possible to measure torque from one of the two drive wheel axles. In this modified configuration, the gear reduction ratio, which is a function of the number of gear teeth, was determined to be 4.113 motor rotations to one axle rotation.

To understand effects of oil temperature on power loss, a system for heating the gearbox lubricating oil to a specified nominal temperature was developed and used during the tests. In this blocked differential configuration, the following measurements were obtained:

- The gear ratio from the motor shaft to the dynamometer was measured, calculated, and documented.

- The gear, windage, cogging, and other friction losses were measured without energizing the generator or the motor. Measurements were obtained with the engine spline free spinning and with it locked.

For motor testing, the engine input spline was allowed to float with either the motor or the dynamometer providing the driving power. During the generator tests, the engine spline was fixed from rotating which effectively locks the planetary carrier arm. In this configuration, the planetary gear train transmitted torque to the generator shaft. Details of the power split device and the gear train that connects the motor to the wheels are presented in Figs. 2.4 and 2.5.

To provide a better understanding of the thermal management system, gearbox lubricating oil temperature and hybrid drive coolant system flow data were collected as part of the overall testing effort. A diagram showing the lubricating and cooling oil inside the three compartments of hybrid drive housing is presented in Fig. 2.3. This figure also presents the hybrid drive coolant system flow rate and pressure that were determined as part of the testing effort. Besides lubricating the bearings and gears, this oil also removes excess heat from the gears, motor, and generator and transfers it to the hybrid drive system coolant.

\subsubsection{Locked Rotor Tests}

A series of locked rotor tests ${ }^{1}$ was performed to determine general operating capabilities of the traction motor. To perform the motor starting torque evaluation, a lever arm was devised and calibrated to a zero cogging torque position that corresponded to zero degrees. The lever arm allowed the motor shaft position to be incrementally moved in degree segments while otherwise remaining locked. Various torque values were produced by supplying current to the motor windings at varying degrees of shaft angle. The resulting data were used to produce a plot, which is shown in Fig. 3.4, that represents torque versus shaft angle at various current levels. Locked rotor torque and current were also studied to characterize the startup torque capability of the motor. Current and corresponding torque values are listed in Table 3.2 and plotted in Fig. 3.5. This series of tests was effective in characterizing the starting torque capability of the 2004 Prius traction motor. 


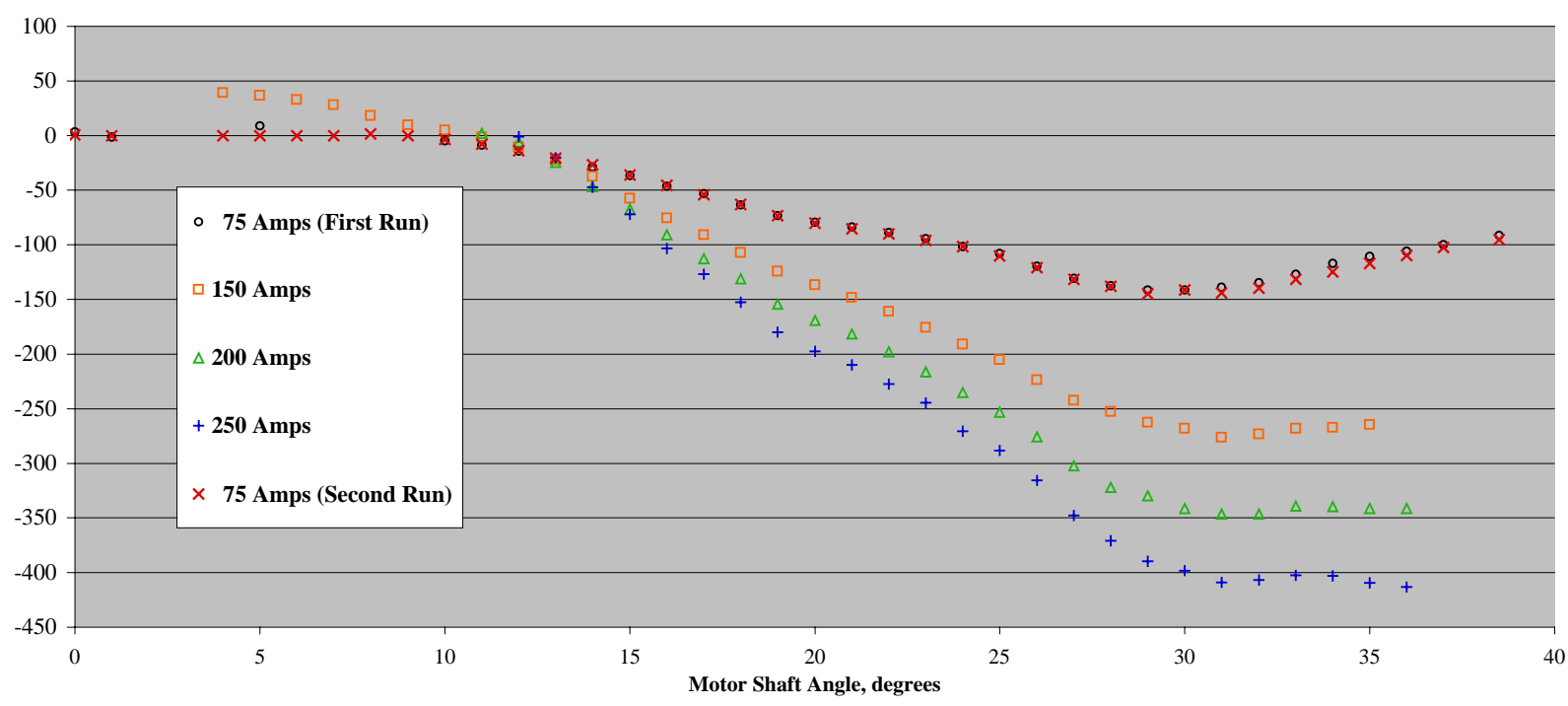

Fig. 3.4. Motor shaft angle versus torque (rotor locked).

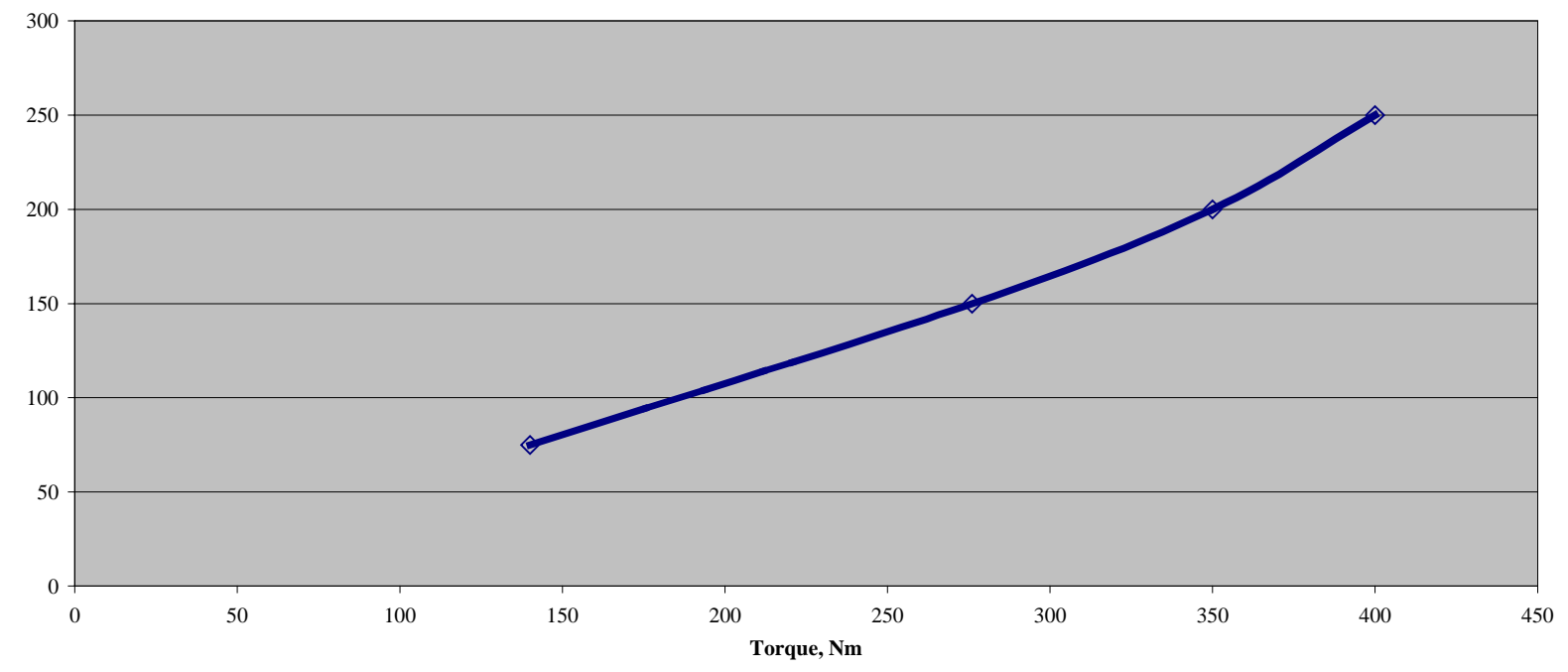

Fig. 3.5. Locked rotor peak torque as a function of current. 
Table 3.2. Motor torque versus motor shaft angle

\begin{tabular}{|c|c|c|c|c|c|}
\hline $\begin{array}{l}\text { Motor shaft } \\
\text { angle, degrees }\end{array}$ & $\begin{array}{c}\text { Motor shaft } \\
\text { torque at } 75 \mathrm{~A} \\
\text { (first run), } \\
\text { Nm }\end{array}$ & $\begin{array}{c}\text { Motor shaft } \\
\text { torque at 150A, } \\
\text { Nm }\end{array}$ & $\begin{array}{c}\text { Motor shaft } \\
\text { torque at 200A, } \\
\text { Nm }\end{array}$ & $\begin{array}{c}\text { Motor shaft } \\
\text { torque at 250A, } \\
\text { Nm }\end{array}$ & $\begin{array}{c}\text { Motor shaft } \\
\text { torque at 75A } \\
\text { (second run), } \\
\text { Nm }\end{array}$ \\
\hline 0.0 & 3.3 & - & - & - & 0.88 \\
\hline 1.0 & -1.5 & - & - & - & - \\
\hline 4.0 & - & 39 & - & - & - \\
\hline 5.0 & 8.9 & 37 & - & - & - \\
\hline 6.0 & - & 33 & - & - & - \\
\hline 7.0 & - & 28 & - & - & - \\
\hline 8.0 & - & 18 & - & - & 1.66 \\
\hline 9.0 & - & 9.7 & - & - & - \\
\hline 10.0 & -4.9 & 4.8 & - & - & -3.51 \\
\hline 11.0 & -8.8 & -1.4 & 1.9 & - & -7.8 \\
\hline 12.0 & -14 & -10 & -5.9 & -0.9 & -13.7 \\
\hline 13.0 & -20 & -22 & -24 & -20 & -20.5 \\
\hline 14.0 & -29 & -38 & -47 & -47 & -26.8 \\
\hline 15.0 & -37 & -58 & -67 & -72 & -36.1 \\
\hline 16.0 & -46 & -76 & -91 & -103 & -45.4 \\
\hline 17.0 & -53 & -91 & -113 & -127 & -54.1 \\
\hline 18.0 & -63 & -107 & -131 & -153 & -62.9 \\
\hline 19.0 & -73 & -124 & -154 & -180 & -73.2 \\
\hline 20.0 & -80 & -137 & -169 & -198 & -80 \\
\hline 21.0 & -83 & -148 & -181 & -210 & -85.4 \\
\hline 22.0 & -89 & -161 & -198 & -227 & -90.2 \\
\hline 23.0 & -94 & -176 & -216 & -244 & -96.1 \\
\hline 24.0 & -101 & -191 & -235 & -271 & -101 \\
\hline 25.0 & -108 & -205 & -253 & -288 & -110 \\
\hline 26.0 & -120 & -223 & -276 & -316 & -121 \\
\hline 27.0 & -131 & -242 & -302 & -348 & -132 \\
\hline 28.0 & -138 & -253 & -322 & -371 & -138 \\
\hline 29.0 & -141 & -262 & -330 & -390 & -145 \\
\hline 30.0 & -141 & -268 & -341 & -398 & -141 \\
\hline 31.0 & -139 & -276 & -346 & -409 & -144 \\
\hline 32.0 & -135 & -273 & -346 & -407 & -140 \\
\hline 33.0 & -127 & -268 & -339 & -402 & -132 \\
\hline 34.0 & -117 & -267 & -340 & -403 & -125 \\
\hline 35.0 & -111 & -265 & -341 & -409 & -117 \\
\hline 36.0 & -106 & - & -341 & -413 & -110 \\
\hline 37.0 & -100 & - & - & -410 & -102 \\
\hline 38.5 & -91 & - & - & - & -95.1 \\
\hline
\end{tabular}




\subsubsection{Back EMF Tests}

The back-emf voltage generated by the motor and the generator was measured using two slightly different hybrid electric drive system configurations. Test conditions and component arrangements for the motor and generator tests are defined in Table 3.3. During the tests, an oscilloscope was used to measure both $\mathrm{rms}^{\ddagger}($ Vrms) and peak (Vpeak) back-emf voltage values.

Table 3.3. Test conditions for back-emf voltage measurements

\begin{tabular}{lcc}
\hline \multicolumn{1}{c}{ Test condition } & Motor tests & Generator tests \\
\hline Shaft speed range, rpm & 500 to 6000 & 1000 to 6500 \\
Oil temperature range, ${ }^{\circ} \mathrm{C}$ & 25 to 80 & 25 to 80 \\
Motor rotor & Installed & Installed \\
Oil pump & Installed & Installed \\
Sun gear & Installed & Installed \\
Planetary gears & Installed & Installed \\
Rotating components: & & \\
$\bullet \quad$ Motor & Functional & Functional \\
$\bullet \quad$ Generator & Idle & Functional \\
$\bullet \quad$ Planetary gears & Idle & Functional \\
\hline
\end{tabular}

\subsubsection{Motor Tests}

Measured back-emf voltage values from the motor are shown in Table 3.4 and plotted in Fig. 3.6. The lubricating oil temperature during this motor test was a nominal $25^{\circ} \mathrm{C}$. It should be noted that the Vpeak to Vrms ratio is greater than the square root of 2 because of the harmonics content in the back emf.

Table 3.4. Back-emf voltage measurements for the 2004 Prius motor

\begin{tabular}{rccccc}
\hline $\begin{array}{c}\text { Axle } \\
\text { speed, } \\
\text { rpm }\end{array}$ & $\begin{array}{c}\text { Motor shaft } \\
\text { speed, rpm }\end{array}$ & $\begin{array}{c}\text { Axle } \\
\text { torque, Nm }\end{array}$ & Frequency, Hz & $\begin{array}{c}\text { Scaled back } \\
\text { emf (Vrms) }\end{array}$ & $\begin{array}{c}\text { Scaled back } \\
\text { emf (Vpeak) }\end{array}$ \\
\hline 122 & 502 & 8.0 & 33.8 & 42.0 & 75 \\
243 & 1000 & 8.4 & 66.5 & 85.7 & 150 \\
365 & 1502 & 9.3 & 99.8 & 132.3 & 225 \\
486 & 1999 & 10.2 & 134.4 & 181.6 & 300 \\
608 & 2501 & 10.8 & 168.1 & 221.8 & 350 \\
729 & 2999 & 11.3 & 200.2 & 269.3 & 425 \\
851 & 3501 & 12.0 & 233.9 & 315.7 & 500 \\
972 & 3999 & 12.6 & 265.4 & 354.6 & 575 \\
1094 & 4501 & 13.1 & 295.7 & 405.5 & 625 \\
1215 & 4999 & 13.6 & 333.0 & 440.4 & 700 \\
1337 & 5500 & 14.6 & 366.3 & 503.4 & 775 \\
1458 & 5998 & 15.6 & 401.3 & 539.8 & 850 \\
\hline
\end{tabular}

Note: Testing was conducted with the differential gears blocked from rotating and oil near room temperature.

\footnotetext{
${ }^{\ddagger}$ Root mean square (rms).
} 


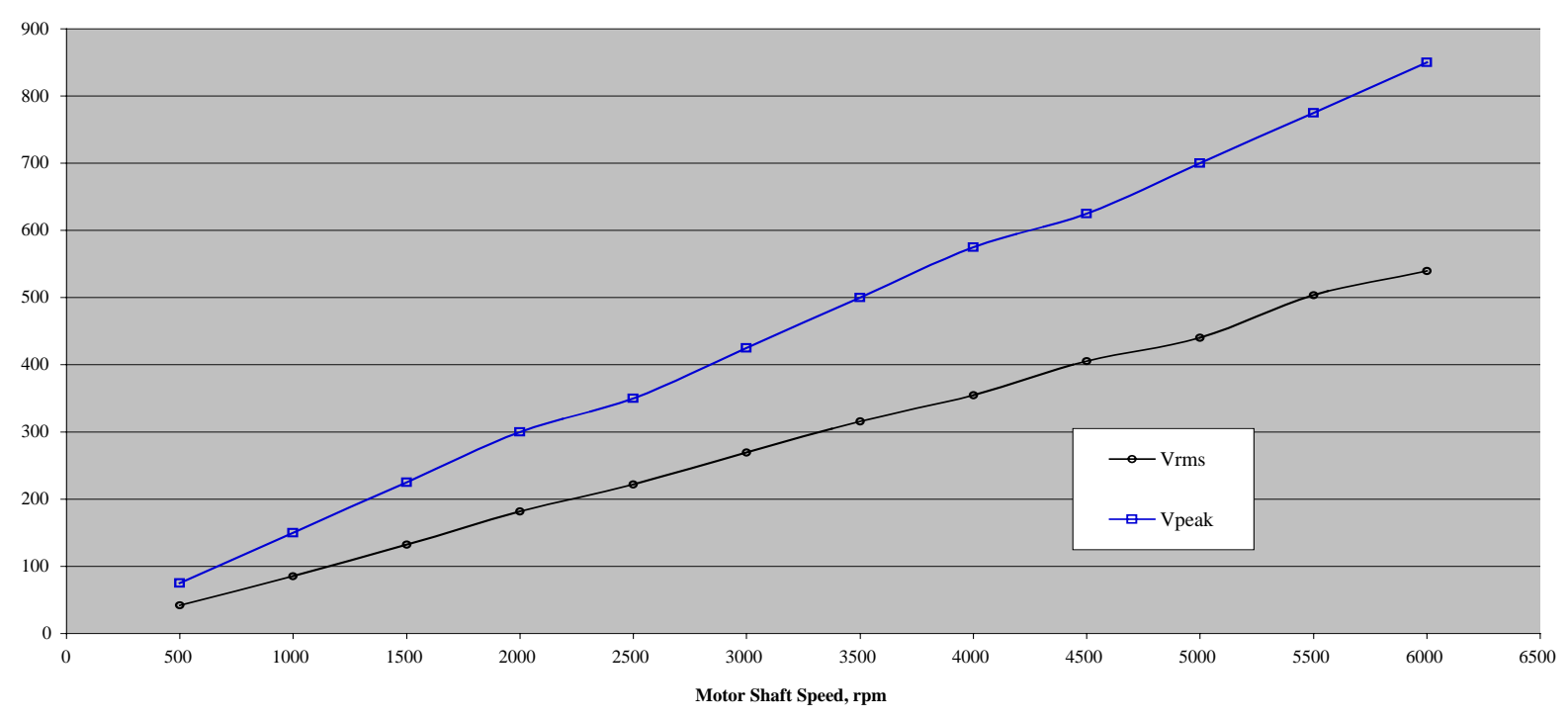

Fig. 3.6. Motor back-emf voltage versus motor shaft speed.

\subsubsection{Generator Tests}

Measured back-emf voltage values from the generator are shown in Table 3.5 and plotted in Fig. 3.7. The lubricating oil temperature during this generator test was a nominal $80^{\circ} \mathrm{C}$.

Table 3.5. Back-emf voltage measurements for the 2004 Prius generator

\begin{tabular}{cccccc}
\hline $\begin{array}{c}\text { Axle } \\
\text { speed, } \\
\text { rpm }\end{array}$ & $\begin{array}{c}\text { Generator } \\
\text { shaft speed, } \\
\text { rpm }\end{array}$ & $\begin{array}{c}\text { Axle } \\
\text { torque, } \mathbf{N m}\end{array}$ & Frequency, Hz & $\begin{array}{c}\text { Scaled back } \\
\text { emf (Vrms) }\end{array}$ & $\begin{array}{c}\text { Scaled back } \\
\text { emf (Vpeak) }\end{array}$ \\
\hline 100 & 1070 & 8.2 & 70.0 & 31.6 & 52.5 \\
150 & 1605 & 9.4 & 109.4 & 49.4 & 80.0 \\
200 & 2140 & 9.6 & 141.3 & 67.0 & 110.0 \\
250 & 2675 & 9.0 & 180.6 & 83.5 & 135.0 \\
300 & 3210 & 9.1 & 213.3 & 96.5 & 160.0 \\
350 & 3745 & 9.5 & 247.9 & 113.5 & 190.0 \\
400 & 4280 & 10.2 & 287.0 & 134.5 & 210.0 \\
450 & 4815 & 10.8 & 320.6 & 144.5 & 240.0 \\
500 & 5350 & 11.3 & 357.9 & 167.0 & 260.0 \\
550 & 5885 & 11.6 & 392.2 & 182.0 & 290.0 \\
600 & 6420 & 12.2 & 430.5 & 195.0 & 320.0 \\
\hline
\end{tabular}

Note: Testing was conducted with the differential gears blocked from rotating and a nominal oil temperature of $80^{\circ} \mathrm{C}$. 


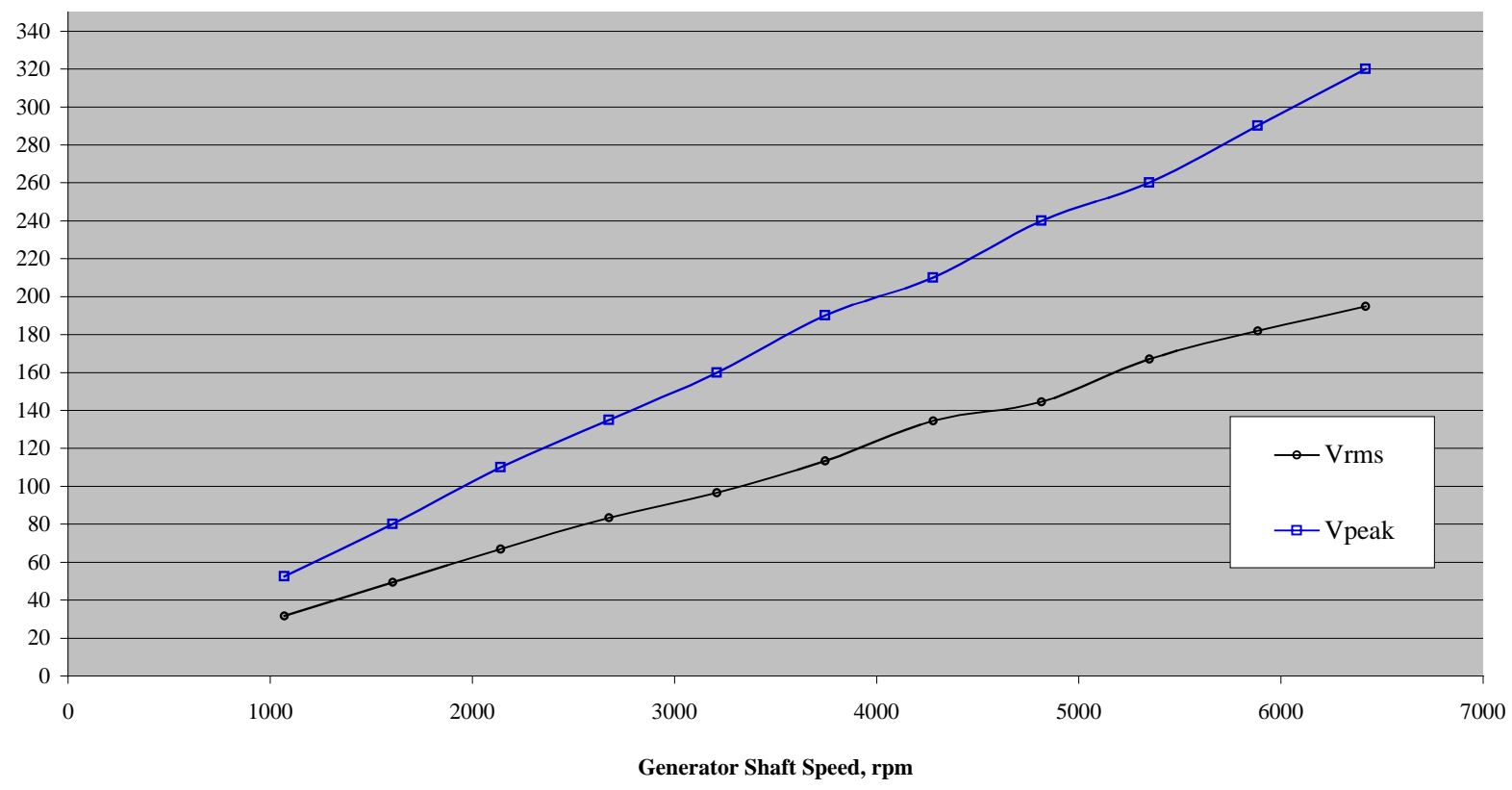

Fig. 3.7. Generator back-emf voltage versus generator shaft speed.

In order to mechanically link the generator into the system, the engine shaft was not allowed to rotate during the tests (i.e., the planetary carrier was fixed from rotating). Using this arrangement allowed the generator to either drive or be driven by the hybrid drive gear train. The location of the planetary carrier relative to the other hybrid electric drive system components is shown in Fig. 2.4.

\subsubsection{Hybrid Drive System Losses Tests}

Three types of power losses that affect the overall efficiency of the hybrid electric drive system were studied. These losses, which are reported in watts (W), include: (1) gear losses; (2) motor rotor losses; and (3) planetary gears, sun gear, and generator rotor losses. Determining the magnitude of each of these types of losses was achieved by separately testing three hybrid drive system configurations at different motor shaft speeds and lubricating oil temperatures. Components installed as part of each configuration are identified in Table 3.6.

Table 3.6. Component configurations for loss determinations

\begin{tabular}{lccc}
\hline \multicolumn{1}{c}{ Component } & Configuration A & Configuration B & Configuration C \\
\hline Engine & Not installed & Not installed & Not installed \\
Motor rotor & Installed & Removed* & Removed \\
Generator rotor & Installed & Installed & Removed \\
Sun gear & Installed & Installed & Removed \\
Planetary gears & Installed & Installed & Removed \\
$\begin{array}{l}\text { Main drive gears, drive } \\
\text { chain, and differential }\end{array}$ & Installed & Installed & Installed \\
\hline
\end{tabular}

*A substitute rotor that provides no loading was installed in place of the motor rotor in order to provide the necessary mechanical support for the adjacent gearbox and planetary components. 
Overall power loss for the entire hybrid drive system was determined by testing the components included in Configuration A. Losses associated with the motor rotor were determined by testing the components included in Configuration B. These tests were conducted with the motor rotor removed and a simulated rotor $^{\ddagger}$ installed in its place. For Configuration $\mathrm{C}$ additional components including the generator rotor, sun gear, and planetary gears were removed leaving only the main drive gears, drive chain, and differential. Under these test conditions, it was possible to determine the gear losses. This testing approach also made it possible to determine losses associated with the planetary gears, generator rotor, and sun gear by subtracting the motor rotor losses and the gear losses from the losses for the entire hybrid electric drive system. Loss values determined with the lubricating oil near room temperature are shown in Table 3.7 and plotted in Fig. 3.8.

Table 3.7. Summary of hybrid drive system losses

\begin{tabular}{rrrccc}
\hline $\begin{array}{c}\text { Axle } \\
\text { speed, } \\
\text { rpm }\end{array}$ & $\begin{array}{c}\text { Motor } \\
\text { shaft } \\
\text { speed, } \\
\text { rpm }\end{array}$ & Gear losses, W & $\begin{array}{c}\text { Motor rotor } \\
\text { losses, W }\end{array}$ & $\begin{array}{c}\text { Planetary gears, generator } \\
\text { rotor, and sun gear losses, } \\
\text { W }\end{array}$ & $\begin{array}{c}\text { Hybrid drive } \\
\text { system losses, W }\end{array}$ \\
\hline 120 & 494 & 74.9 & 19.8 & 7.1 & 102 \\
243 & 1000 & 158.5 & 31.6 & 23.7 & 214 \\
366 & 1506 & 261.8 & 60.2 & 33.2 & 355 \\
484 & 1991 & 369.8 & 109.0 & 40.5 & 519 \\
608 & 2501 & 487.9 & 135.9 & 63.6 & 687 \\
731 & 3007 & 617.2 & 161.7 & 84.2 & 863 \\
851 & 3501 & 745.2 & 205.3 & 118.8 & 1069 \\
972 & 3999 & 915.6 & 242.1 & 125.5 & 1283 \\
1095 & 4505 & 1058.2 & 297.4 & 145.2 & 1731 \\
1215 & 4999 & 1220.8 & 323.9 & 186.5 & 2044 \\
1335 & 5492 & 1425.2 & 404.9 & 214.3 & 2383 \\
1460 & 6006 & 1645.3 & 472.8 & 264.9 & \\
\hline
\end{tabular}

Note: Testing was conducted with the differential gears blocked from rotating and oil near room temperature.

\footnotetext{
‡ The simulated rotor was simply a dummy shaft and bearings required to hold the place of the rotor and keep other components in their appropriate positions.
} 


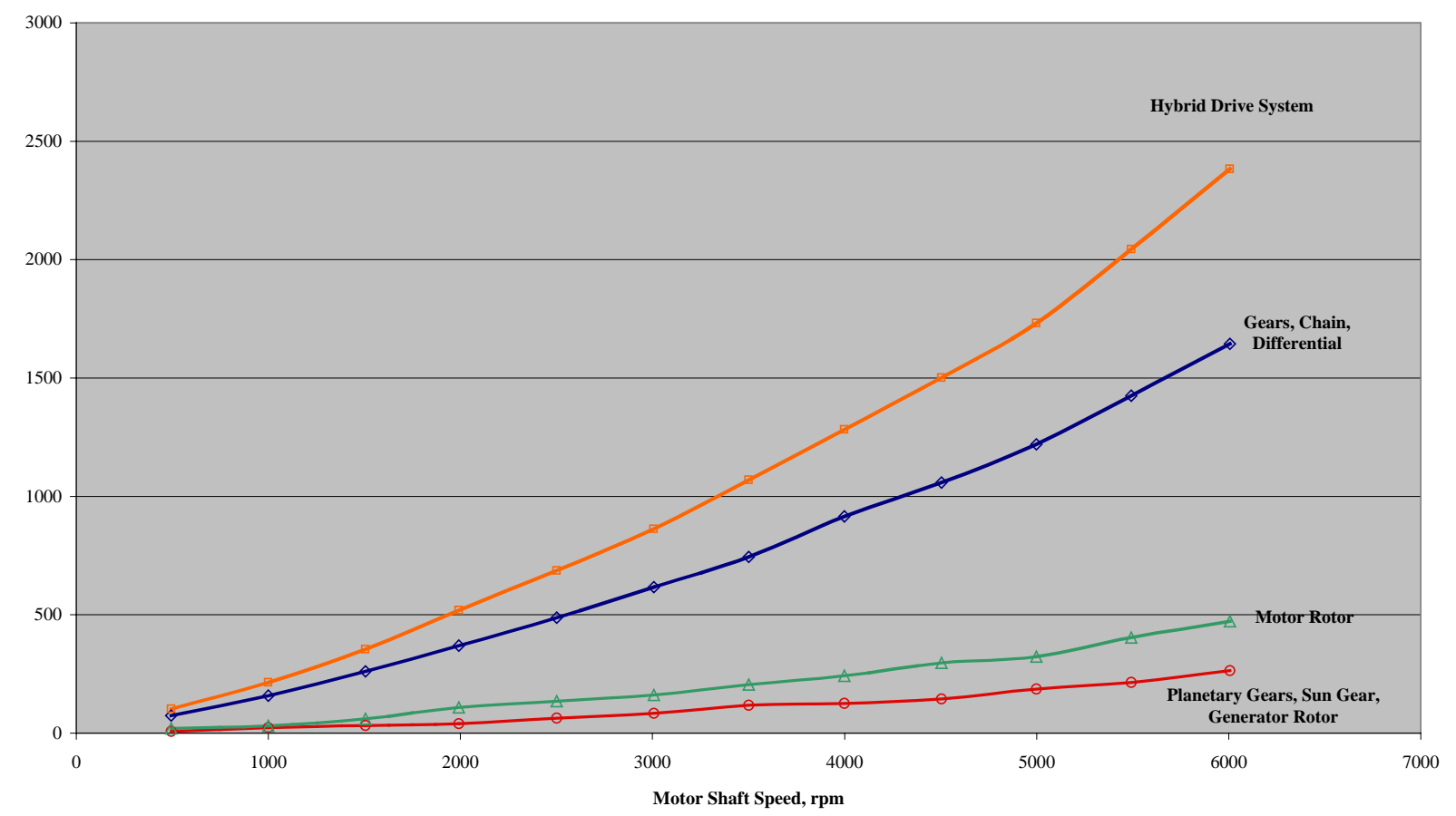

Fig. 3.8. Hybrid electric drive system and component losses at $25^{\circ} \mathrm{C}$.

Losses that were determined for Configuration B at various elevated lubricating oil temperatures are listed in Tables 3.8 to 3.13. As Fig. 3.9 indicates, losses tend to decrease as the lubricating oil temperatures increases.

Table 3.8. Configuration B losses at a nominal oil temperature of $28^{\circ} \mathrm{C}$

\begin{tabular}{ccccc}
\hline Axle speed, rpm & $\begin{array}{c}\text { Motor shaft speed, } \\
\text { rpm }\end{array}$ & Axle torque, Nm & Losses, $\mathbf{~}$ & Oil temperature, ${ }^{\mathbf{C}}$ \\
\hline 122 & 502 & 5.8 & 72.8 & 27.0 \\
243 & 1000 & 6.7 & 170.4 & 27.0 \\
365 & 1502 & 7.6 & 291.1 & 27.0 \\
486 & 1999 & 7.9 & 400.2 & 28.0 \\
608 & 2501 & 8.4 & 534.6 & 28.5 \\
729 & 2999 & 8.9 & 681.0 & 29.0 \\
851 & 3501 & 9.4 & 837.3 & 29.0 \\
972 & 3999 & 9.8 & 997.0 & 29.5 \\
1094 & 4501 & 10.3 & 1180.5 & 30.0 \\
1215 & 4999 & 10.7 & 1360.7 & 30.5 \\
1337 & 5500 & 11.2 & 1565.0 & 31.5 \\
1458 & 6006 & 12.1 & 1849.0 & 32.0 \\
\hline
\end{tabular}


Table 3.9. Configuration B losses at a nominal oil temperature of $40^{\circ} \mathrm{C}$

\begin{tabular}{ccccc}
\hline Axle speed, rpm & $\begin{array}{c}\text { Motor shaft speed, } \\
\text { rpm }\end{array}$ & Axle torque, Nm & Losses, W & Oil temperature, ${ }^{\circ} \mathbf{C}$ \\
\hline 122 & 502 & 5.3 & 66.6 & 40.5 \\
243 & 1000 & 6.0 & 152.6 & 40.5 \\
365 & 1502 & 6.7 & 256.7 & 40.5 \\
486 & 1999 & 7.2 & 364.7 & 41.0 \\
608 & 2501 & 7.7 & 490.0 & 41.0 \\
729 & 2999 & 8.2 & 627.4 & 41.5 \\
851 & 3501 & 8.5 & 757.1 & 42.0 \\
972 & 3999 & 9.1 & 925.8 & 42.5 \\
1094 & 4501 & 9.5 & 1088.8 & 43.0 \\
1215 & 4999 & 10.2 & 1297.1 & 44.0 \\
1337 & 5500 & 10.6 & 1481.1 & 44.5 \\
1458 & 6006 & 11.3 & 1726.8 & 45.0 \\
\hline
\end{tabular}

Table 3.10. Configuration B losses at a nominal oil temperature of $50^{\circ} \mathrm{C}$

\begin{tabular}{ccccc}
\hline Axle speed, rpm & $\begin{array}{c}\text { Motor shaft speed, } \\
\text { rpm }\end{array}$ & Axle torque, $\mathbf{N m}$ & Losses, $\mathbf{~}$ & Oil temperature, ${ }^{\circ} \mathbf{C}$ \\
\hline 122 & 502 & 5.2 & 65.3 & 50.0 \\
243 & 1000 & 6.0 & 152.6 & 50.5 \\
365 & 1502 & 6.5 & 249.0 & 51.0 \\
486 & 1999 & 7.0 & 354.6 & 51.5 \\
608 & 2501 & 7.4 & 470.9 & 51.0 \\
729 & 2999 & 7.9 & 604.4 & 51.5 \\
851 & 3501 & 8.3 & 739.3 & 52.0 \\
972 & 3999 & 8.6 & 874.9 & 52.0 \\
1094 & 4501 & 9.1 & 1043.0 & 52.5 \\
1215 & 4999 & 9.7 & 1233.5 & 53.0 \\
1337 & 5500 & 10.2 & 1425.2 & 53.5 \\
1458 & 6006 & 10.7 & 1635.1 & 54.5 \\
\hline
\end{tabular}


Table 3.11. Configuration B losses at a nominal oil temperature of $60^{\circ} \mathrm{C}$

\begin{tabular}{ccccc}
\hline Axle speed, rpm & $\begin{array}{c}\text { Motor shaft speed, } \\
\text { rpm }\end{array}$ & Axle torque, $\mathbf{~ m ~}$ & Losses, $\mathbf{W}$ & Oil temperature, ${ }^{\circ} \mathbf{C}$ \\
\hline 122 & 502 & 5.0 & 62.8 & 59.5 \\
243 & 1000 & 5.5 & 139.9 & 59.5 \\
365 & 1502 & 6.2 & 237.5 & 60.0 \\
486 & 1999 & 6.8 & 344.5 & 60.0 \\
608 & 2501 & 7.2 & 458.2 & 60.0 \\
729 & 2999 & 7.9 & 604.4 & 60.0 \\
851 & 3501 & 8.3 & 739.3 & 60.0 \\
972 & 3999 & 8.6 & 874.9 & 60.0 \\
1094 & 4501 & 8.9 & 1020.0 & 60.5 \\
1215 & 4999 & 9.4 & 1195.4 & 61.0 \\
1337 & 5500 & 10.0 & 1397.3 & 61.5 \\
1458 & 6006 & 10.6 & 1619.8 & 62.0 \\
\hline
\end{tabular}

Table 3.12. Configuration B losses at a nominal oil temperature of $70^{\circ} \mathrm{C}$

\begin{tabular}{ccccc}
\hline Axle speed, rpm & $\begin{array}{c}\text { Motor shaft speed, } \\
\text { rpm }\end{array}$ & Axle torque, $\mathbf{~ m m}$ & Losses, $\mathbf{W}$ & Oil temperature, ${ }^{\mathbf{C}}$ \\
\hline 122 & 502 & 4.7 & 59.0 & 70.0 \\
243 & 1000 & 5.5 & 139.9 & 70.0 \\
365 & 1502 & 6.2 & 237.5 & 70.0 \\
486 & 1999 & 6.8 & 344.5 & 70.0 \\
608 & 2501 & 7.1 & 451.8 & 70.0 \\
729 & 2999 & 7.7 & 589.1 & 69.5 \\
851 & 3501 & 8.2 & 730.4 & 69.5 \\
972 & 3999 & 8.3 & 844.4 & 69.5 \\
1094 & 4501 & 8.8 & 1008.6 & 70.0 \\
1215 & 4999 & 9.1 & 1157.2 & 70.5 \\
1337 & 5500 & 9.6 & 1341.4 & 71.0 \\
1458 & 6006 & 10.1 & 1543.4 & 71.5 \\
\hline
\end{tabular}


Table 3.13. Configuration $B$ losses at a nominal oil temperature of $80^{\circ} \mathrm{C}$

\begin{tabular}{ccccc}
\hline Axle speed, rpm & $\begin{array}{c}\text { Motor shaft speed, } \\
\text { rpm }\end{array}$ & Axle torque, $\mathbf{N m}$ & Losses, $\mathbf{W}$ & Oil temperature, ${ }^{\circ} \mathbf{C}$ \\
\hline 122 & 502 & 4.0 & 50.2 & 82.5 \\
243 & 1000 & 4.4 & 111.9 & 82.0 \\
365 & 1502 & 5.5 & 210.7 & 80.5 \\
486 & 1999 & 6.1 & 309.0 & 80.5 \\
608 & 2501 & 6.6 & 420.0 & 80.5 \\
729 & 2999 & 7.2 & 550.9 & 81.0 \\
851 & 3501 & 7.8 & 694.8 & 81.0 \\
972 & 3999 & 8.2 & 834.2 & 81.0 \\
1094 & 4501 & 8.5 & 974.2 & 81.0 \\
1215 & 4999 & 8.8 & 1119.1 & 81.5 \\
1337 & 5500 & 9.2 & 1285.5 & 82.0 \\
1458 & 6006 & 9.7 & 1482.3 & 82.0 \\
\hline
\end{tabular}

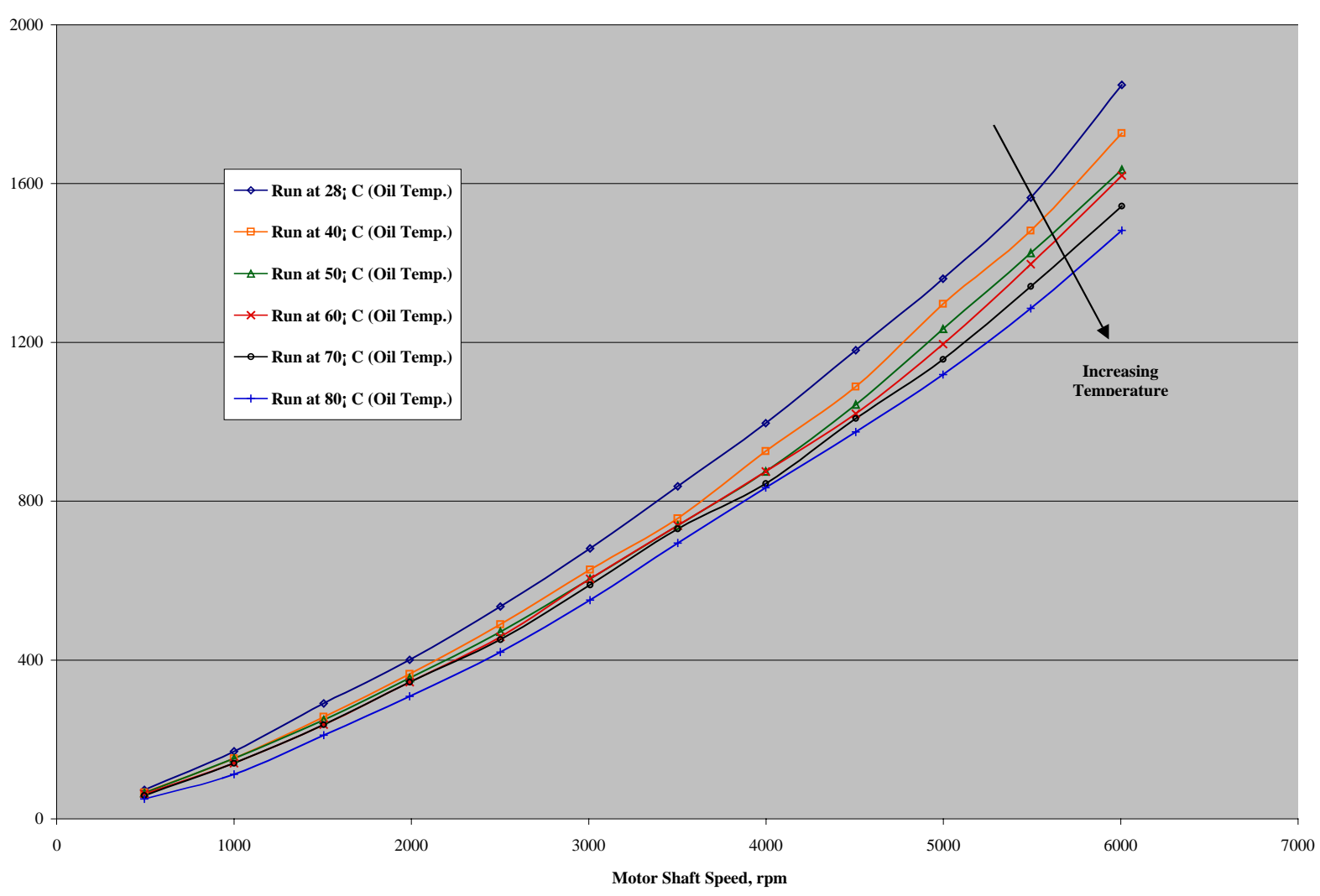

Fig. 3.9. Configuration B losses as a function of oil temperature. 


\section{INVERTER AND CONVERTER EVALUATION}

The inverter that is part of the hybrid electric drive system was partially disassembled to reveal its architecture, to identify its method of cooling, and to understand the manufacturing techniques used in its construction. A description of the inverter and its components is provided in Sect. 2.2.5.

\subsection{FUNCTIONAL AND ARCHITECTURE STUDY}

After careful study of a 2003 and 2004 Prius inverter, differences were noted between the two models. The 2004 inverter is packaged in roughly the same volume as the 2003 unit; however, the 2004 inverter contains the new buck/boost converter in addition to the motor, generator, air conditioning compressor inverter, and dc-to-dc inverter and converter.

The 2004 Prius inverter is cooled using a cold plate located in the center of the package. This cold plate serves as a separator between the generator-motor-boost sections that are located above the cold plate and the air conditioning compressor inverter and dc-to-dc converter located below the cold plate. The cold plate transfers excess heat from the inverter to the hybrid drive system coolant as it circulates through internal passages in the cold plate. A flow diagram for the hybrid drive system coolant is presented in Fig. 2.3. The main inverter sections (motor and generator) are packaged in one module referred to as the "12 pack." The boost converter is a separate module from the 12 pack.

The main dc link capacitors in the 2004 Prius are slightly smaller in volume than those in the 2003 Prius and are packaged in a plastic module making them different from the commercially available can-type electrolytic capacitors used in the 2003 model. Most of the integrated circuits in the 2004 Prius are identified with a Toyota label, as compared to those in the 2003 unit that used commercially available electronic components.

\subsection{CONTROL DEVELOPMENT}

In preparing for future component-level tests, the inverter is being modified to operate and properly control the Prius traction motor and generator while outside the vehicle. Accomplishing this objective requires an understanding of the interface between the inverter and the Prius control system. Speed and position feedback signals need to be understood, and algorithms and interfaces need to be developed to provide control signals to the inverter and converter power devices.

Currently, the RT-LAB real-time computing platform from OPAL-RT Technologies is being used to model and replace the Prius onboard control system. The RT-LAB system interfaces with the MATLAB SIMULINK software for quick controller development without tedious assembler programming. The system consists of a host PC running a user-selected operating system and two target PCs running the QNX Neutrino operating system. One of the PCs is a dual-processor computer with additional counter, encoder, and analog/digital I/O PCI boards.

The model of the Prius controller and a user interface is built in MATLAB SIMULINK using both builtin SIMULINK blocks and RT-LAB blocks. Using the Real-Time Workshop Toolbox of SIMULINK, the model is converted to C-source code and the executable is uploaded to the target PCs. The controller software runs on two target PCs that communicate with each other through a firewire connection while the host computer is used to command the controller through an ethernet connection. The software allows the control development to be flexible and versatile, with the capability of quickly making required development changes. This approach bypasses some of the more difficult hardware development efforts 
required to allow the inverter to be controlled outside the vehicle. It also enhances the ability to make changes during testing, if required.

When this work is completed, inverter performance will be verified by driving simple resistive or inductive loads. After verification is completed, the inverter will then be used to operate the traction motor and generator during the component-level performance tests in a motor test cell.

\subsection{INVERTER MODIFICATIONS AT ANL}

A 2004 Prius inverter is being modified at ANL with installation of instrumentation to allow control of the system and to provide an effective way to monitor power flow through the inverters and converters. Currently, a preliminary version of this instrumentation is being used to perform 2004 Prius testing on the ANL chassis dynamometer. Additional information about these tests is presented in Sect. 3.1.

The inverter that will be used for the ORNL component-level tests is currently being modified with conventional sensors that are similar in design to those installed in the ANL inverter. Changes that are being made include installation of:

1. Shunt-style current sensors on dc link bus bars on both the $200 \mathrm{~V}$ and $500 \mathrm{~V}$ sides of the boost converter,

2. Voltage divider sensing points on the $200 \mathrm{~V}$ and $500 \mathrm{~V}$ bus bars,

3. A shunt-style current sensor on the $12 \mathrm{~V}$ auxiliary charging system, and

4. A shunt-style current sensor on the $200 \mathrm{~V}$ dc-to-dc converter for the air conditioning compressor inverter drive.

Additional inverter instrumentation is required to achieve all the ORNL component-level testing goals. This additional instrumentation is non-standard and involves developmental sensors and installation techniques. Issues related to this development include:

- Installation of Giant Magneto Resistive (GMR) current sensors directly on the dc bus bars (embedded in the module) to sense current in the feed to the traction motor inverter section.

- Installation of GMRs on the dc bus bars that feed the generator inverter section.

The GMRs, which supplement the conventional sensors being installed on the inverter and converter sections, are much more difficult to install and are very intrusive into the inverter, thus requiring very careful design and installation. These special sensors are important because they will allow power flow inside the inverter and converter package to be resolved (separate power flow to and from the motor and power flow from the generator are normally mixed on the internal dc link and packaged so tightly inside the housing that it is difficult to measure as separate power quantities). These sensors were specified because they are very small and the space in which they are being placed is very restricted, and because they provide a way to resolve all the separate power flows in the hybrid electric drive system. This instrumentation scheme, which is depicted in Fig. 3.1, will allow ORNL to best evaluate the operating methods and electrical and thermal performance of the hybrid electric drive system.

Inverter modifications by ANL are nearing completion and the unit should be ready for operation in the near future. 


\section{SUMMARY AND CONCLUSIONS}

This interim report describes the portion of the 2004 Prius hybrid electric drive system evaluation that has been completed to date. To minimize possible confusion, results of the evaluation are subdivided into two separate discussions depending on the location where the work was performed.

Vehicle-level (chassis dynamometer based) performance testing was conducted at the APRF located at ANL. Testing involved the following activities:

- Completion of basic instrumentation required for monitoring the inverter,

- Installation of a shaft torque sensor,

- Development of an interface with the onboard Toyota diagnostics computer,

- Collection of initial data, and

- Calibration checks of the testing equipment and instrumentation.

Further testing will be conducted at the ANL facility in fiscal year 2005.

Component-level performance and validation testing was conducted at the PEEMRC located at ORNL. Testing involved:

- Characterizing overall motor performance,

- Performing locked rotor tests at varying torque angles,

- Collecting back-emf voltage waveforms for both the generator and traction motor, and

- Determining gear, bearing, and other friction losses for various operating speeds and lubricating oil temperatures.

Additional tests will be conducted at the ORNL facility the first quarter of fiscal year 2005.

Results of follow-on testing will be documented in a final report that will include a comparison of vehicle-level and component-level performance.

\subsection{FINDINGS AND OBSERVATIONS}

Initial vehicle-level data collected at ANL shows that the data acquisition scheme would provide adequate data to determine efficiencies of the basic hybrid electric drive system components such as the motor, generator, and inverter. It must reflect patterns and control schemes during various parts of a driving cycle. Sensor calibrations and equipment checks are needed to validate the data. This work is currently proceeding.

Component-level testing at ORNL revealed that gearbox related friction losses were found to be significant. These losses are approximately $2.4 \mathrm{~kW}$ at a motor speed of $6000 \mathrm{rpm}$. The predominant loss of about $1.6 \mathrm{~kW}$ is associated with the main reduction gears and drive chain, while the motor, power split device, and generator yielded losses of about $0.8 \mathrm{~kW}$. Gear train losses are primarily associated with oil splashing within the hybrid drive housing and oil slinging from the generator and motor rotors to provide needed lubrication and removal of excess heat. These losses, which are summarized in Table 5.1, were determined with the lubricating oil at or near room temperature (about $25^{\circ} \mathrm{C}$ ). The tests also revealed that 
overall losses decreased about $20 \%$ when the temperature of the lubricating oil increased from 27 to $80^{\circ} \mathrm{C}$. This finding indicates that total losses for the hybrid electric drive system equal approximately $1.9 \mathrm{~kW}$ at a lubricating oil temperature of $80^{\circ} \mathrm{C}$.

Table 5.1. Summary of gear train losses at $25^{\circ} \mathrm{C}$

\begin{tabular}{lc}
\hline \multicolumn{1}{c}{ Component } & $\begin{array}{c}\text { Contribution to loss, } \\
\%\end{array}$ \\
\hline $\begin{array}{l}\text { Reduction Gears and } \\
\text { Drive Chain }\end{array}$ & 68 \\
Motor Rotor & 21 \\
Generator and & 11 \\
$\quad$ Planetary Gears & \\
\hline
\end{tabular}

Gear reduction ratios were determined and documented for both the motor rotor and the generator rotor (with engine spline locked). This determination was primarily performed to allow accurate calculation of speed, torque, and loads, but the findings also provided a basis for comparison with other drives and to identify engineering choices and compromises that were made as part of the overall design process. The following relationships are based on results of the gear reduction determinations:

$$
\begin{array}{lll}
2004 \text { Prius Motor Speed } & = & (4.113)(\text { Axle Speed }) \\
2003 \text { Prius Motor Speed } & = & (3.905)(\text { Axle Speed }) \\
2004 \text { Prius Generator Speed } & = & (10.7) \text { (Axle Speed with engine spline locked) }
\end{array}
$$

Motor and generator testing yielded back-emf voltage and frequency data. During the tests, a dynamometer drive was used to control motor speed and generator speed. Results of the back-emf testing are summarized in Table 5.2.

Table 5.2. Summary of back-emf test results

\begin{tabular}{lc}
\hline \multicolumn{1}{c}{ Test conditions } & Results \\
\hline Motor Back emf (6000 rpm) & $540 \mathrm{Vrms}$ \\
Motor Volts/Hertz & $1.33 \mathrm{Vrms} / \mathrm{Hz}$ \\
Generator Back emf (6420 rpm) & $195 \mathrm{Vrms}$ \\
Generator Volts/Hertz & $0.46 \mathrm{Vrms} / \mathrm{Hz}$ \\
\hline
\end{tabular}

A series of locked rotor tests was performed to determine general operating capabilities of the traction motor. In particular, the torque and current were studied during the locked rotor tests to characterize the startup torque capability of the motor. Current and corresponding torque values are presented in Table 5.3 and discussed in detail in Ref. 1. 
Table 5.3. Summary of motor current and torque test results

\begin{tabular}{cc}
\hline Current, A & Maximum torque, Nm \\
\hline 75 & 140 \\
150 & 260 \\
250 & 400 \\
\hline
\end{tabular}

\subsection{NEEDED RESEARCH AND DEVELOPMENT}

Research and development activities that need to be accomplished to finalize electrical and mechanical performance characterization of the THS II include the following tasks:

1. Receive the modified inverter from ANL and conduct the THS II inverter performance testing. This work will be conducted at ORNL.

2. Evaluate thermal performance of the inverter under normal, full-load conditions. This work will be conducted at ORNL.

3. Evaluate the THS II hybrid drive thermal performance under normal, full-load conditions using the inverter to power the system. This work will be conducted at ORNL.

4. Continue the vehicle-level testing at ANL. This work will involve validating testing equipment calibration and finishing the vehicle-level performance evaluation of the THS II system. Data collected from these efforts will be used for comparison to data taken from the component-level testing being conducted at ORNL.

5. Evaluate the ANL and ORNL data sets and prepare a final report that describes the testing that was conducted to characterize the vehicle-level and component-level performance of the 2004 Toyota Prius. 


\section{REFERENCES}

1. J. S. Hsu, C. W. Ayers, C. L. Coomer, R. H. Wiles, S. L. Campbell, K. T. Lowe, and R. T. Michelhaugh, Report on Toyota/Prius Motor Torque Capability, Torque Property, No-Load Back EMF, and Mechanical Losses, ORNL/TM-2004/185, UT-Battelle, LLC, Oak Ridge National Laboratory, Oak Ridge, Tennessee, October 2004.

2. Prius Repair Manual, 1, Pub. No. RM1075U1, Toyota Motor Corporation, 2003.

3. Prius Repair Manual, 2, Pub. No. RM1075U2, Toyota Motor Corporation, 2003.

4. Prius Repair Manual, 3, Pub. No. RM1075U3, Toyota Motor Corporation, 2003.

5. J. S. Hsu, C. W. Ayers, and C. L. Coomer, Report on Toyota/Prius Motor Design and Manufacturing Assessment, ORNL/TM-2004/137, UT-Battelle, LLC, Oak Ridge National Laboratory, Oak Ridge, Tennessee, August 2004. 
ORNL/TM-2004/247

\title{
INTERNAL DISTRIBUTION
}

\author{
1. D. J. Adams \\ 2-4. C. W. Ayers \\ 5. E. C. Fox \\ 6-8. J. S. Hsu \\ 9-11. L. D. Marlino \\ 12. S. C. Nelson, Jr.
}

13. C. B. Oland

14. G. W. Ott, Jr.

15. R. H. Staunton

16. Central Research Library

17-18. ORNL Laboratory Records (OSTI)

19. ORNL Laboratory Records (RC)

\section{EXTERNAL DISTRIBUTION}

20. S. A. Rogers, U.S. Department of Energy, EE-2G/Forrestal Building, 1000 Independence Avenue, S.W., Washington, D.C. 208585.

21. E. J. Wall, U.S. Department of Energy, EE-2G/Forrestal Building, 1000 Independence Avenue, S.W., Washington, D.C. 208585. 